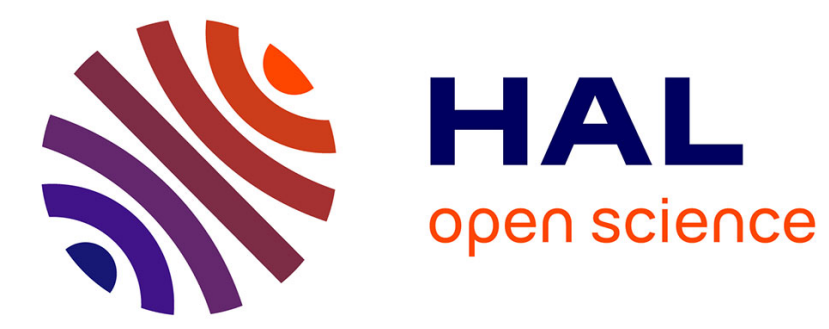

\title{
Invited review: A critical appraisal of mastitis vaccines for dairy cows
}

Pascal Rainard, Florence Gilbert, Pierre Germon, Gilles Foucras

\section{To cite this version:}

Pascal Rainard, Florence Gilbert, Pierre Germon, Gilles Foucras. Invited review: A critical appraisal of mastitis vaccines for dairy cows. Journal of Dairy Science, 2021, 104 (10), pp.10427-48. 10.3168/jds.2021-20434 . hal-03293669

\section{HAL Id: hal-03293669 \\ https://hal.inrae.fr/hal-03293669}

Submitted on 21 Jul 2021

HAL is a multi-disciplinary open access archive for the deposit and dissemination of scientific research documents, whether they are published or not. The documents may come from teaching and research institutions in France or abroad, or from public or private research centers.
L'archive ouverte pluridisciplinaire HAL, est destinée au dépôt et à la diffusion de documents scientifiques de niveau recherche, publiés ou non, émanant des établissements d'enseignement et de recherche français ou étrangers, des laboratoires publics ou privés.

\section{(ㅇ)(1) $\$$}

Distributed under a Creative Commons Attribution - NonCommercial - NoDerivatives| 4.0 


\section{A critical appraisal of mastitis vaccines for dairy cows}

2 Pascal Rainard $^{1 *}$, Florence B. Gilbert ${ }^{1}$, Pierre Germon ${ }^{1}$, and Gilles Foucras ${ }^{2}$

3

$4 \quad{ }^{1}$ ISP, INRAE, Université de Tours, UMR1282, Nouzilly, France

${ }^{2}$ IHAP, INRAE, ENVT, Université de Toulouse, Toulouse, France

6

$7 \quad *$ Corresponding author Pascal Rainard

\section{ABSTRACT}

Infections of the mammary gland remain a frequent disease of dairy ruminants that negatively impact animal welfare, milk quality, farmer serenity, farming profitability, and increases use of antimicrobials. There is a need for efficacious vaccines to alleviate the burden of mastitis in dairy farming, but despite decades of research this need has not been satisfactorily fulfilled. A careful appraisal of past and current research on mastitis vaccines reveals the peculiarities but also the commonalities among mammary gland infections associated with the major mastitis pathogens, Escherichia coli, Staphylococcus aureus, Streptococcus uberis, S. agalactiae or S. dysgalactiae. A major pitfall is that the immune mechanisms of effective protection have not been fully identified. Until now, vaccine development has been directed towards the generation of antibodies. In this review, we drew up an inventory of the main approaches used to design vaccines aiming at the major pathogens for the mammary gland, and critically appraised the current and tentative vaccines. In particular, we sought to relate efficacy to vaccine-induced defense mechanisms, in order to shed light on some possible reasons for current vaccine shortcomings. Based on the lessons learned from past attempts and the recent results of current research, the design of effective vaccines may take a new turn in the years to come. 
Keywords: cattle; mammary gland; mastitis; adaptive immunity; vaccine

\section{INTRODUCTION}

Mastitis is one of the most costly diseases in the dairy industry, costing US dairy industry up to

$\$ 2$ billions per year and from $€ 17$ to $€ 198$ per cow at the farm level in Europe (Hogeveen et al.,

2011). In addition to its economic impact, mastitis is also of concern regarding animal welfare and farmer serenity. Mastitis, even subclinical, affects milk quality and can be a source of foodborne pathogens, such as livestock- associated Methicillin Resistant S. aureus (LA-MRSA) (Goerge et al., 2017, Garcia et al., 2019). Mastitis is the most common reason for antimicrobials use in dairy farms, and a prudent use of antibiotics is recommended (Ruegg, 2017). As the widespread prophylactic use of antibiotics is no longer sustainable, and considering its importance as a mastitis control practice, an additional or replacement procedure is needed. This is only partly achieved by internal teat sealants along with selective dry cow therapy (Bradley et al., 2010). Efficacious vaccines, by reducing the incidence of new infections and

the occurrence of clinical cases, would be an appropriate and convenient way to fulfill this need. Most mastitis cases are caused by the so-called major pathogens, Staphylococcus aureus, Streptococcus uberis, Streptococcus agalactiae, Streptococcus dysgalactiae, Escherichia coli, and Klebsiella pneumoniae. Documented reviews on S. aureus vaccines are available that present in detail the results obtained in field experiments, their merits and limitations (Middleton et al., 2009, Scali et al., 2015, Côté-Gravel et al., 2019). Vaccines directed at other major pathogens are less well covered (Keane, 2019). Vaccine development faces a number of hurdles. Some relate to the return on investment, which is conditioned by the size of the market and by the acceptability of the vaccine, which largely depends on its proven effectiveness. 
These uncertainties certainly dampen the enthusiasm or will of developers, which in turn reduces investment in research and therefore progress. These issues are not dealt with in this review. The purpose of this review on mastitis vaccines is to assess current knowledge, including newly released vaccines, with a particular attention to the supposed defense mechanisms put to effect by vaccination. This approach will help to analyze the possible reasons for the disconnect between expectations and reality, and to devise alternative or complementary means for the development of mastitis vaccines.

\section{COLIFORM MASTITIS VACCINES}

\section{Escherichia coli J5 Mastitis Vaccines}

Intramammary infections (IMI) by Gram-negative bacteria ("coliforms") have long been the major cause of clinical mastitis of dairy cows worldwide, and are still a major challenge for mastitis research (Ruegg, 2017). In the late 1970s, mastitis control programs based on teat dipping and dry cow therapy were found to be effective in controlling staphylococcal and streptococcal mastitis, but had little effect on coliform infections. Only tedious control methods (improved hygiene of bedding and walking corridors by frequent removal of manure or flushing) had effectively reduced coliform mastitis under field conditions (NRC et al., 1979). In the late 1980s, evidence began to emerge that vaccination with bacterins made up of killed rough E. coli and adjuvant had some efficacy against clinical coliform mastitis in cows (Wilson and Gonzalez, 2003). The rationale behind the use of rough E. coli was that they were purported to elicit antibodies cross-reacting with mastitis strains of different serotypes and protective against these strains in models of infection or endotoxemia by passive transfer of immune serum (Ziegler et al., 1973, Ziegler et al., 1982, Sakulramrung and Domingue, 1985). The most studied rough mutant was the J5 mutant derived from an O111:B4 E. coli strain. This mutant lacks oligosaccharide side chains of the lipopolysaccharide (LPS), so that the core LPS, which is 
nearly identical to that of most other Gram-negative bacteria, is exposed at the surface of bacteria. The immunization with normal pathogenic smooth strains of Gram-negative bacteria induces the formation of serotype-specific antibodies directed at the $\mathrm{O}$ side chains, but usually little if any antibodies to the core region or to membrane-associated proteins (Baumgartner and Glauser, 1993). It is likely that $\mathrm{O}$ antigens are immunodominant when compared to core antigens and that they prevent the induction of antibodies to core epitopes. The drawback is that there are about $180 \mathrm{E}$. coli different O-serotypes and that none is prevalent among mastitisassociated strains (Linton et al., 1979, Linton and Robinson, 1984, Stenutz et al., 2006). Several studies have established that immunization with smooth wild-type strains of Gram-negative bacteria elicits protection against a challenge with the homologous strain, contrary to immunization with rough mutants, reviewed in (Greisman and Johnston, 1997). The protection afforded by core-antigen antibodies is thus a controversial topic.

Nevertheless, vaccines based on J5 mutant strains attracted the interest of mastitis researchers and were used as a component of the control of clinical coliform mastitis in parturient and early lactation cows. The observation that dairy cows with low ELISA titers of $\mathrm{IgG}_{1}$ to $E$. coli $\mathrm{J} 5$ were associated with five times the rate of clinical coliform mastitis compared to animals with higher titers (Tyler et al., 1988) elicited interest in immunization with rough mutants of Gram-negative bacteria. Several field studies were carried out, mainly with the mutant strain J5 but also with a rough mutant of Salmonella enterica Typhimurium Re-17 strain, as reviewed by (Wilson and Gonzalez, 2003). In the late 1980s, evidence emerged that vaccination of cows with J5 bacterins had some efficacy against clinical coliform mastitis. The bacterins were administered by the subcutaneous route on several occasions, often at dryingoff, with a booster before calving and another after calving, with significant reductions in the incidence of clinical mastitis in vaccinated compared to unvaccinated cows (Gonzalez et al., 1989, Cullor, 1991, Hogan et al., 1992a). A vaccine based on the use of killed Salmonella Re- 
17 produced a comparable reduction in clinical cases of coliform mastitis and mortality rate (McClure et al., 1994), raising interrogation about the underlying mechanisms other than the developement of cross-reactive antibody immunity, as discussed below.

An early study of the financial return on the use of the J5 vaccine indicated that when more than $1 \%$ of cow lactations were affected by clinical coliform mastitis, the vaccination would be profitable (DeGraves and Fetrow, 1991). The efficiency of a recently licensed vaccine against coliform and staphylococcal mastitis (Startvac ${ }^{\circledR}$, Hipra SA) has been investigated in a field study: there was no decrease in the incidence rate of clinical mastitis, but mastitis severity was significantly reduced, with lessened milk losses resulting in a return on investment of 2.57 to 1 (Bradley et al., 2015). It has been proposed that through the reduction in milk production losses and replacement of culled or dead cow, J5 vaccination is profitable in herds that experience cases of clinical mastitis by Gram-negative bacteria beyond a threshold of more than $4 \%$ of lactating cows per month (Wilson and Gonzalez, 2003). An overview of the main coliform vaccine trials is given in Table 1.

\section{Supposed Mechanisms of Protection by J5 Vaccines}

Remarkably, the relative success of rough Gram-negative bacteria vaccines remains unexplained in terms of their underlying mechanisms. The initial rationale for these vaccines was that they could elicit antibodies capable of neutralizing the toxic activity of the lipid A moiety of LPS and opsonizing mastitis-associated coliform bacteria. Early studies in mice and humans indicated that passive transfer of antibodies induced by $\mathrm{J} 5$ immunization protected against endotoxic shock (Ziegler et al., 1982). However, the neutralization of endotoxic activity is controversial. Several attempts of passive transfer of antibodies to J5 were unsuccessful, possibly because of insufficient antibody concentration, so that the use of J5 antiserum to prevent or treat endotoxic shock is not of standard medical practice (Cross, 2014). As lipid A 
is responsible for the toxicity of LPS, monoclonal antibodies to lipid A have been developed for the therapy of Gram-negative sepsis. However, their efficiency has been doubted as they did not consistently show neutralizing activity (Warren et al., 1993). The treatment of calves with J5 antiserum did not protect against shock induced by intravenous LPS injection (Morris et al., 1986). Antibodies to the core part of LPS have also been tested for protective activity. Coupling the core glycolipid to a carrier protein improved the immunogenicity and resulted in higher antibody titers than those elicited by a J5 bacterin vaccine (Cross et al., 2014). However, there are five different $E$. coli core antigens (K-12, R1, R2, R3 and R4) that can induce corespecific antibodies. A mixture of those core antigens conjugated to a protein carrier was used to vaccinate cows. Compared to control cows, SCC and E. coli shedding in milk did not differ in vaccinated animals after intramammary challenge, although high titers of antibodies to the core type of the challenge strain had been elicited (Brade et al., 2013). It is not even certain that the J-5 vaccines induce antibodies to the core LPS, as one study suggested that the raised antibodies were not directed to rough LPS but to outer membrane proteins such as OmpA (Chaiyotwittayakun et al., 2004).

Several studies have investigated the effect of J5 vaccines on the opsonic activity of serum and milk of vaccinated cows. The focus has been on the induction of antibodies that are opsonic for neutrophils of dairy ruminants, i.e. $\operatorname{IgG}_{2}$ and $\operatorname{IgM}$ antibodies, as these antibodies play a major role in the opsonization of E. coli (Williams and Hill, 1982, Hill et al., 1983a). Most natural opsonic antibodies to E. coli are of the IgM isotype and usually there is little $\operatorname{IgG}_{2}$ activity in the serum and milk of unimmunized cows (Williams and Hill, 1982). Natural infection of the mammary gland (MG) elicits opsonic antibodies, but they are serotype specific (Hill et al., 1983a). Immunization with smooth bacteria can induce opsonic antibodies in serum and milk (Rainard, 1983, Herry et al., 2017), but these antibodies are mainly serotype-specific, which make them useless given the multiplicity of serotypes among mastitis-causing coliform 
bacteria (Linton et al., 1979, Sanchez-Carlo et al., 1984, Lipman et al., 1995). To obviate the narrow specificity of opsonic antibodies, J5 bacterins were used to induce cross-reactive opsonic antibodies. It appeared that eliciting antibodies to J5 bacteria in the IgG2 sub-isotype was difficult, requiring more than three administrations to reach significantly higher than initial titers (Chaiyotwittayakun et al., 2004). Increased $\mathrm{IgG}_{2}$ antibodies to J-5 obtained by hyperimmunization correlate with a decreased occurrence of clinical mastitis (Erskine et al., 2007). However, antibody titers tend to dwindle in a few months (Erskine, 2012).

The opsonic activity of antibodies raised with J5 bacterins is a matter of controversy. Studies showed either some increase in opsonic activity following vaccination (Hogan et al., 1992b) or not (Vreede et al., 1986). The antibodies bound to their antigen target have to be accessible to the phagocytes, and specifically to their immunoglobulin receptors, for ingestion to be triggered. First, the antigen targets must be accessible to antibodies. The accessibility of lipid A, core antigens and outer membrane proteins has been doubted, owing to the shielding effect of the side chains of LPS (O-antigen) of smooth strains (Greisman and Johnston, 1997). This shielding has been confirmed with mastitis strains: immunization of cows with J5 induced cross-reactive antibodies to rough strains but these antibodies, except those directed at fimbriae, reacted very poorly with smooth strains and did not improve on the opsonic activity of preexisting natural antibodies (Figure 1) (Rainard et al., 2021). Absorption of J5 immune serum with smooth strains did not reduce the antibody reactivity with rough strains, demonstrating the efficient shielding by the O-antigen polysaccharide layer toward outer membrane antigens. In accordance, immunization of rabbits with E. coli J5 did not augment the opsonization titer to smooth strains (van Dijk et al., 1981). Nevertheless, J5 bacterins induce cross-reactive antibodies, even though their specificity has not been characterized (Ziegler et al., 1973), except for the outer membrane protein OmpA and type 1 fimbriae (Rainard et al., 2021). The role played by these cross-reacting antibodies in protection against infection has been evaluated in 
vaccination and challenge experiments. Several studies did not find noticeable protective effect following systemic or intramammary J5 vaccination (Hill, 1991, Smith et al., 1999, Tomita et al., 2000, Steele et al., 2019, Tashakkori et al., 2020, Vangroenweghe et al., 2020). One study found that the J5 vaccine was associated with faster clearance of E. coli in milk and less reduction in milk yield following an intramammary challenge with a strain that did not induce clinical mastitis (Wilson et al., 2007). Of note, the $\operatorname{IgM}$ and $\mathrm{IgG}_{2}$ milk titers were not different from titers of control cows just before challenge, and higher IgM antibody titers against J5 at $12 \mathrm{~h}$ post-challenge tended to be associated with higher milk production losses, suggesting that the vaccine effect was probably independent of opsonic antibodies.

The vaccine formulation is likely to account for part of the discrepant results of experimental challenges. The comparison of two J5 vaccines using two different adjuvants yielded different outcomes, one showing some protection and the other none compared to control cows (Hogan et al., 2005). The route of administration could also influence the efficacy of the vaccine. The common way of J5 vaccine administration is subcutaneous injection in the neck. A study compared this route to the area drained by the supramammary lymph node, without much difference in efficacy, with a comparable increase in antibody titers to J5 (Tomita et al., 1998). In another vaccine trial, the two J5 vaccines tested failed to improve serum and mammary secretion $\operatorname{IgM}$ antibody titers but increased $\operatorname{IgG}_{1}$ and $\operatorname{IgG} 2$ titers, with no change in clinical status of challenged cows among treatment groups (Tomita et al., 2000). The E. coli strains used for the challenge are also likely to affect the results of vaccine trials. In all of these experiments, the role of anti-J5 antibodies was not established. One study showed a slight augmentation of phagocytosis of a smooth E. coli strain after vaccination with $\mathrm{J} 5$ that was attributed to a slight augmentation of $\operatorname{IgM}$ antibodies to the smooth strain in the serum of vaccinated cows, although there was no increase of titers to J5 (Hogan et al., 1992b). The specificity of the opsonic antibodies was not determined. It 
appeared that $\mathrm{J} 5$ vaccines elicit antibodies to molecules protruding from the $\mathrm{O}$-antigen shield, such as type 1 fimbriae, which can bind to smooth strains (Rainard et al., 2021). Since a proportion of mastitis E. coli isolates have the genetic equipment to produce these structures (Lipman et al., 1995), and as fimbriae are supposed to contribute to adhesion to mammary epithelial cells (MECs), antibodies to fimbriae could play a role in vaccine-induced protection. However, their opsonic activity has not been evidenced (Rainard et al., 2021). Another type of fimbriae, the long polar fimbriae, can be produced by mastitis strains and could be associated with the ability to invade MECs (Dogan et al., 2012). Their role in mastitis pathogenesis and the possible contribution of antibodies to these fimbriae to mammary defense is worth investigating.

All things considered, the importance of opsonic antibodies as a defense mechanism induced by $\mathrm{J} 5$ vaccines is questionable. The observation that early lactation pooled whey (5-10 days post-partum) was opsonic for all mastitis strains of $E$. coli tested suggests that since early lactation milk contains sufficient opsonins, severe E. coli mastitis at this stage of lactation is not due to opsonic deficiency (Hill et al., 1983b). In other words, opsonic antibodies are not a limiting factor in defense against $E$. coli mastitis even in early lactation when coliform mastitis tends to be severe. This conclusion is supported by the absence of reinforcement of milk neutrophils phagocytic activity at the onset of infection in the quarters of vaccinated cows challenged with the homologous strain compared to control cows, although antibody titers to this strain were markedly augmented in the $\mathrm{IgG}_{2}$ and IgM isotypes (Herry et al., 2017). Another factor contributing to reducing the potential benefit of vaccine-induced antibodies is the difficulty in maintaining elevated concentrations because of dilution in milk. It can be concluded that the role of J5 vaccine-induced opsonic antibodies remains dubious and that the experimental challenge trials displayed limited protection and did not yield many clues as to the mechanism behind the activity of the $\mathrm{J} 5$ vaccine observed in field experiments. 
As an alternative to the role of the antibody response, it has been proposed that $\mathrm{J} 5$ vaccines promote a $\mathrm{T}$ cell-mediated immunity polarized towards a $\mathrm{T}$ helper type 1 (Th1)

response (Dosogne et al., 2002). Vaccination by the systemic route would induce memory helper T cells, some of which would home into the mammary tissue (Taylor et al., 1994). There, these lymphocytes would increase the recruitment and activation of neutrophils through the secretion of cytokines on presentation of E. coli antigens at the onset of infection, finally allowing the cow to cope more effectively with the bacteria. The benefit of this response might be most appropriate around parturition, a time when the immune response of cows seems to be biased towards Th2 type immune responses (Shafer-Weaver et al., 1999). Indeed, a systemic (subcutaneous) immunization of cows with a model antigen such as ovalbumin can elicit an antigen-specific pathway in the MG (De Cueninck, 1979). A hallmark of this cell-mediated immune response is the accelerated or amplified influx of neutrophils at the onset of infection, as exemplified by the reinforced recruitment of leukocytes upon challenge of cows immunized intramammarily with killed E. coli (Rainard, 1983). Experimental infections of cows vaccinated with J5 bacterins do not support this cell-mediated hypothesis. In one study, the authors specify that "the SCC did not differ between treatments in speed or magnitude of response" (Hogan et al., 1995). No amplified neutrophil recruitment was reported in other experimental challenges (Hill, 1991, Hogan et al., 1992c, Smith et al., 1999, Tomita et al., 2000). There is no evidence either supporting the improvement of the neutrophil phagocytic or bactericidal activity following $\mathrm{J} 5$ vaccination. Remarkably, the induction of $\mathrm{T}$ cell-mediated immune response by $\mathrm{J} 5$ vaccines has not been investigated.

The mechanisms of protection observed in field studies with $\mathrm{J} 5$ vaccination remain unclear (Baumgartner et al., 1991). It has been suggested that J5 vaccines may reduce the severity of mastitis by acting more on the systemic immune response than on the local mammary defenses (Erskine, 2012). The mechanism is elusive. We have seen that the 
hypothesis of endotoxin activity neutralization by antibodies has not been validated. Antibodies to lipid A or core antigens (passive transfer of immune plasma or IVIG or mAb) have been mainly considered to alleviate sepsis, not to combat infection limited to an infected organ, as it occurs in coliform mastitis. The induction of opsonic antibodies is at best marginal with the licensed protocols of vaccination, and their contribution to protection can be questioned. The experimental challenge experiments did not confirm the hypothesis of cell-mediated immunity manifesting itself by an amplified influx of neutrophils at the onset of infection. The downside stemming from our ignorance of protection mechanisms is that we are unable to optimize the $\mathrm{J} 5$ vaccine on a rational basis.

\section{Sub-unit Vaccines against Coliforms}

Another approach to vaccination against coliform mastitis has been explored. Blocking the growth of coliform bacteria in mammary secretions has the potential to prevent IMI rather than reducing only its severity. Iron is an essential element for the survival and multiplication of coliform bacteria. Most iron in mammary secretions is bound to lactoferrin during the dry period and to citrate during lactation (Reiter, 1978). Coliform bacteria can acquire iron in bodily fluids by utilizing high-affinity iron acquisition systems (Garenaux et al., 2011). Two of those systems have been targeted to develop a mastitis vaccine. The enterobactin iron acquisition system is common in coliforms isolated from mastitis. The ferric enterobactin receptor FepA, which is an iron-regulated outer membrane protein, binds ferric enterobactin, an efficient iron chelator (siderophore). Cows were immunized with purified FepA, and the serum IgG fraction tested for bacteriostatic activity (Lin et al., 1999): the growth of all the E. coli and Klebsiella pneumoniae isolates tested was inhibited by $4 \mathrm{mg} / \mathrm{mL}$ of the $\operatorname{IgG}$ preparation in the presence à $0.5 \mathrm{mg} / \mathrm{mL}$ apolactoferrin. Of note, purified IgG from cows immunized with E. coli J5 had little inhibitory effect on the growth of E. coli or K. pneumoniae mastitis isolates (Lin et al., 1999). 
The authors suggested that antibodies to FepA could help the MG to deal with E. coli during the dry period when lactoferrin concentrations are high in mammary secretion. Another inducible siderophore receptor, the ferric citrate receptor FecA (Braun, 1997), is likely to play an important role for coliform mastitis isolates as citrate concentration is high $(7-11 \mathrm{mM})$ in milk (Gaucheron, 2005), the fecABCD operon is present in most, if not all, mastitis E. coli strains (Goldstone et al., 2016), and loss of expression causes a loss of pathogenicity for the MG (Blum et al., 2018). Cows were immunized twice by the subcutaneous and once by the intramammary routes with either purified FecA or J5 vaccine, with a control unimmunized group (Takemura et al., 2002). There was no difference between groups in bacterial counts after challenge, duration of infection, milk somatic cell counts or milk production, showing that the FecA and J5 vaccination were ineffective, despite an increase in antibody titers to FecA in the serum of the FecA immunized cows. Purified IgG from FecA-immunized cows had little effect on the growth of E. coli in vitro under Fe-restricted conditions (Takemura et al., 2004). In the conclusion of their in vitro and in vivo trials on blocking the growth of E. coli by immunizing cows with bacterial ferric iron receptors, the authors deemed that this vaccination approach may not be feasible because the required effective antibody concentrations could not be induced and maintained in milk (Wolf et al., 2004).

In the same line of thought, a K. pneumoniae bacterial extract was used as the active principle of a vaccine for Klebsiella mastitis in dairy cattle (KLEBVax ${ }^{\mathrm{TM}}$ SRP, Epitopix, Willmar, Minnesota) recently licensed by the USDA. This vaccine is based on the proprietary patented SRP® (Siderophore Receptor and Porin) technology, which consists in extracting bacterial surface proteins of a representative mastitis $K$. pneumoniae isolate, used as antigens for active immunization. A field trial was carried out in a university dairy farm in which Klebsiella mastitis caused $14 \%$ of all clinical cases, $19 \%$ of which led to the death of the cows (Gorden et al., 2018). All cows were vaccinated with a commercially available J5 vaccine. The 
Klebsiella SRP® extract was emulsified in oil-in-water adjuvant and two subcutaneous doses administered three weeks apart to half the cows, the other half receiving a placebo (adjuvant only). In all, 229 pairs of cows were analyzed. There was no significant difference in culling because of Klebsiella pneumoniae mastitis between groups (10 vs 19 in vaccinated vs control cows) or coliform mastitis other than Klebsiella (6 vs 5) or in clinical cases of Klebsiella mastitis ( 31 vs 38 ) or of coliform mastitis (65 vs 81 ). However, cows vaccinated before calving had less SCC and milk losses than control cows. The concurrent administration of a J5 vaccine and the different schedules of administration of the Klebsiella vaccine complicated the study, as a positive effect on the number of clinical cases and milk production occurred only when the first injection took place before calving. The SRP antigen induced antibodies, but their protective activity was not established. Another study involving more than 3000 cows did not show any effect of the KLEBVax ${ }^{\mathrm{TM}}$ vaccine, either on the incidence of clinical mastitis or the postcalving risk of death or culling in relation to Klebsiella spp. Mastitis (Tomazi et al., 2021). In the latter study, a new vaccine based on the recombinant protein YidR, highly conserved between mastitis Klebsiella pneumoniae isolates but also with Escherichia coli strains, was evaluated in a study involving more than 3000 cows. It is impossible to judge the efficacy against $E$. coli mastitis because the cows also received a $\mathrm{J}-5$ vaccine, even in the control placebo group (aluminum hydroxide adjuvant only). The main positive result of the two injection of the vaccine, one at drying-off, the other before calving, was a reduction (about $37 \%, \mathrm{p}<0.05$ ) of the adjusted incidence of clinical mastitis (Tomazi et al., 2021). The mechanism associated with this effect remains elusive. In particular, the ELISAs used to measure the antibody response showed a high baseline level against the purified recombinant protein or whole bacteria, little increase elicited by the vaccine wuth the recombiantn protein and no significant increase with whole Klebsiella. 
Intramammary immunization during the dry period with a bacterial extract from a

smooth mastitis strain (P4) has been carried out to test the influence of the route of immunization and the possibility to protect at least against the homologous challenge strain (Herry et al., 2017). Compared to a protocol involving two subcutaneous injections, the protocol including a local (intramammary) booster immunization was more successful, by improving bacterial clearance while limiting inflammation. Of note, the efficiency of opsonisation and neutrophil-dependent bactericidal activity in milk was not improved by the vaccination, despite a sizable increase in antibody titers to the O-antigen of the challenge strain. It is thus possible that the improved MG defenses were not linked to strain-specific antigens, but rather to the route of immunization. Indeed, a further analysis of data from CD4 $\mathrm{T}$ cell gene expression indicated that IL-17 and type 3 immunity-related T cells had been elicited in the mammary tissue of locally immunized glands (Cebron et al., 2020).

\section{STREPTOCOCCAL VACCINES}

\section{Streptococcus uberis Mastitis Vaccines}

Streptococcus uberis tends to be the most common cause of clinical mastitis in pasture-based dairy herds in regions and countries with a temperate humid climate such as New Zealand, the UK, Ireland and France (Denis et al., 2009, Petrovski et al., 2011, Green and Bradley, 2013, Keane et al., 2013, Poutrel et al., 2018). Current strategies aiming at reducing the incidence of IMI by S. uberis are not very effective so that the control of these infections remains problematic, a situation that makes efficient vaccines a highly desirable but so far elusive goal despite multiple attempts (Denis et al., 2009, Klaas and Zadoks, 2018). An early attempt to vaccinate against $S$. uberis mastitis used live bacteria of a virulent strain (0140J) administered by the subcutaneous route and a bacterial surface extract intramammarily seven days after drying-off(Hill et al., 1994). Vaccinated cows challenged with the vaccine strain shed $10^{5}$ times 
lower bacterial concentration and more than 10 times lower leukocyte concentrations in milk than unvaccinated animals. Interestingly, although specific antibacterial antibodies were elicited in the $\mathrm{IgG}_{2}$ and $\operatorname{IgM}$ isotypes, the opsonic activity of serum or milk was not improved, despite a modest initial phagocytic activity (50\% bacterial survival). Contrary to vaccination with a surface extract of the challenge strain, which did not induce protection, the live vaccine induced a proliferative response of blood lymphocytes to S. uberis antigen. A further study showed that vaccination with live bacteria protected against the homologous strain but was less effective against a heterologous strain (Finch et al., 1997). Another attempt indicated that local vaccination (intramammary) with killed bacteria without adjuvant administered six times one week apart during the dry period protected the gland against homologous challenge by preventing bacterial growth without inflammation (Finch et al., 1994). Again, the opsonic activity of milk or serum of vaccinated cows was not improved. Furthermore, in experimental MG infections with virulent strains of $S$. uberis, intense recruitment of neutrophils into mammary tissue and milk occurred concomitantly with high concentrations of bacteria, which were not frequently observed associated with neutrophils (Hill et al., 1994, Thomas et al., 1994). Those findings were surprising. Indeed, the phagocytic killing of bacteria by neutrophils is considered an essential defense of the MG, a position supported by cogent arguments with regard to mastitis-associated E. coli and S. aureus (Paape et al., 2002). Accordingly, the prompt and intense recruitment of activated neutrophils at the onset of infection is assumed to have a positive effect on the outcome of infection (Craven and Williams, 1985, Rainard and Riollet, 2003). These views may not apply to S. uberis mastitis, an oddity that prompted investigations on the interactions of $S$. uberis with phagocytic cells.

The investigation of a small panel of five S. uberis clinical isolates exposed to bovine neutrophils in the presence of skim milk displayed three phenotypes: bacteria that resisted phagocytosis when cultured in laboratory medium (strain C197C), bacteria that became 
resistant when cultured in medium supplemented with casein hydrolysate (strains 0140J and ST10), and bacteria susceptible to phagocytosis under both conditions (strains EF20 and CC21) (Leigh and Field, 1991). A previous study, involving the most susceptible strain (EF20) and a resistant strain (0140J), had shown that both could produce a hyaluronic capsule and that the susceptibility to the bactericidal activity of neutrophils was not dictated by the capsule (Leigh et al., 1990). In effect, strain EF20, which loses its capsule at the stationary phase of culture, was equally susceptible to phagocytosis at the exponential and stationary phases, and the decapsulation of strain $0140 \mathrm{~J}$ with hyaluronidase did not render it susceptible to phagocytosis. Those two strains had shown different pathogenicity for the lactating MG, as the strain EF20 failed to induce mastitis most of the time, whereas the strain 0140J was usually successful (Hill, 1988). Surprisingly, the strain EF20 was eliminated from inoculated glands in the absence of neutrophil influx, thus challenging the presupposed view that the difference in pathogenicity of the two strains was linked to their differing resistance to phagocytosis. It should be noted that the two strains were equally efficient at inducing mastitis in dry MG. Further studies with strain 0140J showed that the presence of the capsule appears to contribute to resistance to phagocytosis as neutrophils killed 0140J acapsular mutants (Ward et al., 2001). Nevertheless, other studies have indicated that although the hyaluronic acid capsule contributes to resistance to phagocytosis, it was not required for strain $0140 \mathrm{~J}$ to induce clinical mastitis (Field et al., 2003). Intriguingly, the authors explained the inefficiency of the MG phagocytic defense by a potent antiphagocytic activity exerted by the strain 0140J culture supernate. This inefficiency is consistent with in vivo data that has shown that bacterial numbers in milk remain high despite a massive influx of neutrophils (Field et al., 2003). The identity of this putative inhibitor and its mode of action have not been established. Among antiphagocytic streptococcal factors, hyaluronic acid has been reported to prevent attachment of streptococci to macrophages (Whitnack et al., 1981). It is worth noting that not all S. uberis isolates are able to produce a 
capsule even at their primary in vitro culture (Matthews et al., 1994b), but that most of the strains isolated from mastitis possess the genes (has $A B C$ ) required for capsule synthesis (Field et al., 2003).

Contrary to neutrophils, macrophages obtained from dried MGs were able to phagocytose a strain resistant to phagocytosis by neutrophils, in the presence of $\operatorname{IgG}_{1}$ or $\operatorname{IgG}_{2}$ antibodies from normal serum, independently of complement (Grant and Finch, 1996). This observation is in keeping with the experimental infection of the lactating MG with S. uberis showing that bacteria were seen within macrophages but not within neutrophils (Thomas et al., 1994). Mammary gland macrophages were able to take up capsulated or unencapsulated mastitis isolates of $S$. uberis, but the capsule reduced phagocytosis and intracellular killing (Almeida and Oliver, 1993). In these studies, the bactericidal efficacy of MG macrophages appeared to be limited even in the presence of serum, consistent the idea that MG macrophages have depressed phagocytic and pro-inflammatory functions, especially milk macrophages during lactation (Denis et al., 2006).

All these results suggest that phagocytosis by neutrophils and macrophages (at least during lactation) is not an effective defense of the MG against S. uberis (Leigh, 1999). Consequently, several other avenues have been followed to develop effective vaccines. One of them stemmed from the observation that effective vaccine trials showed protection of the gland without inflammation and prevented bacterial growth in vivo (Hill et al., 1994). S. uberis are fastidious bacteria that are auxotrophic for at least eight amino-acids (Leigh, 2000). One way streptococci acquire their nutrients in the $\mathrm{MG}$ is by activating milk plasminogen and binding the activated plasmin to their surface, thus being able to use peptides from hydrolyzed milk proteins for their growth and multiplication (Leigh and Lincoln, 1997). The plasminogen activator PauA is produced by most mastitis isolates of $S$. uberis and is highly conserved across strains (Johnsen et al., 1999). A small-scale vaccine experiment with PauA showed that 
neutralizing antibodies were induced that coincided with reduced severity of mastitis, low bacterial shedding, and low milk leukocytosis compared to unvaccinated control cows (Leigh et al., 1999). A remarkable aspect of this protective effect is that it was obtained with a reduction rather than an increase in inflammation as usual with other vaccines. Moreover, inflammation could well promote the growth of S. uberis in the MG, possibly by the activation of inflammasome and the production of IL-1 $\beta$ by macrophages (Archer et al., 2020).

However, PauA would not be a requirement for S. uberis to grow in milk (Ward et al., 2003), which casts some doubt on the effectiveness of a vaccine based exclusively on this antigen. It has been shown that the glyceraldehyde-3-phosphate dehydrogenase GapC contributes to the binding of plasmin at the bacterial surface (Cunningham, 2000). Vaccination of cows with recombinant $S$. uberis GapC or CAMP factor was reported to induce protection after homologous challenge (Fontaine et al., 2002), but peculiarities of the challenge model (low virulence of the $S$. uberis strain, size or viability of the inoculum) made this experiment unconvincing (Leigh, 2002). Field studies with PauA, GapC, or CAMP subunit vaccines are awaited.

Another avenue of research for vaccine design derived from the observation that various S. uberis strains have been shown to adhere in vitro to a mammary epithelial cell line (MAC-T cells) and to be actively internalized (Matthews et al., 1994a). In MAC-T cells, S. uberis can survive for several days (Tamilselvam et al., 2006). By using primary cultures of mammary epithelial cells, adhesion occurred readily only to cells that had lost their microvilli (Ditcham et al., 1996). However, adherence and invasion of intact mammary epithelial cells have not been confirmed using mammary tissue explants (Thomas et al., 1992), and examination of mammary tissue after experimental infection with $S$. uberis revealed bacteria adhering only to damaged epithelium (Thomas et al., 1994). There are two conflicting views on the adherence and invasion of MECs by S.uberis, one which posits that adhesion and invasion is a central 
mechanism in the pathogenesis of S. uberis mastitis (Almeida et al., 2015), another considering that adhesion is not required and cannot play a major role in the initiation of infection (Leigh, 1999). Adherence and invasion of MAC-T cells depend on the presence of the surface S. uberis adhesion molecule (SUAM) (Almeida et al., 2006). Antibodies obtained by immunizing cows with recombinant SUAM reduced the adherence and internalization of $S$. uberis by MAC-T cells (Prado et al., 2011). Infection of the MG with a mastitis isolate and its isogenic mutant devoid of SUAM showed that the defective mutant induced mastitis of lesser intensity with fewer bacterial shedding and milk leukocytosis (Almeida et al., 2015). However, bacterial shedding and milk leukocytosis were still sizable, indicating that SUAM was not the only virulence factor at play during MG infection. In an experimental S. uberis intramammary challenge involving 40 cows half of which were vaccinated with SUAM and adjuvant, all the cows developed mastitis (Siebert et al., 2017). These results suggest that SUAM alone would not suffice to design an efficient vaccine, and would need to be associated with other antigen targets.

A possible way $S$. uberis could resist MG immune defenses and antimicrobial treatments is the formation of biofilm. Biofilms are dense aggregates of surface-adherent microorganisms embedded in a complex matrix mainly comprising exopolysaccharides. Most if not all S. uberis mastitis isolates can grow in biofilm under suitable culture conditions (Crowley et al., 2011, Dieser et al., 2017). In particular, casein proteolytic peptides contribute to increased biofilm formation, conditions likely to occur during MG infection (Varhimo et al., 2011). A recently licensed vaccine produced by Laboratorios Hipra S. A. (UBAC®) is based on a slime preparation as antigen (Collado et al., 2018). The Biofilm Adhesion Component (BAC) comprises an extract of biofilm produced by a mastitis isolate cultivated on a solid surface and extracted by autoclaving. This complex antigen contains lipoteichoic acid (LTA). The antigen preparation is adjuvanted with monophosphoryl lipid A (MPLA), and emulsioned water-in-oil 
475 in Montanide ISA (mineral oil; Seppic, France). The vaccine is administered by the 476 intramuscular route on three occasions, two months before calving, about 40 days later, finally 477 about 15 days after calving. A trial involving experimental infection with a strain different from the vaccine strain has been conducted with 13 vaccinated and 12 control cows. The initial response to the challenge was similar in the two groups, but the clinical score was lower in the vaccinated group 3 days after challenge, and bacterial shedding after six days. Milk production losses were reduced in the vaccinated group. Nevertheless, milk leukocytosis was similar and high (more than $10^{6}$ cells $/ \mathrm{mL}$ during the first 8 days) in the challenged quarters in both groups. Antibodies to LTA increased in the vaccinated group, and immune serum was somewhat active in reducing biofilm formation. Since control cows only received PBS injection, a potential nonspecific immunostimulation due to the presence of MPLA and adjuvant in vaccinated cows could have contributed to the results obtained. The results of a field study were presented at the National Mastitis Council Conference in Milan (Puig et al., 2018). Involving 401 vaccinated and 380 control cows in six herds, the study showed a reduction in clinical mastitis cases in vaccinated animals compared to controls $(6.1 \%$ vs $13.5 \%)$ through reduction in infection severity, but the impact on the milk yield was small ( 36.8 vs $36.4 \mathrm{~L} /$ day). The effect of vaccination on phagocytosis by neutrophils or adherence to MECs was not reported.

In all the studies mentioned above, the contribution of vaccine-induced antibodies to MG defense was either doubtful (opsonic antibodies) or not unquestionably established (prevention of adherence and invasion). Most attempts to improve the immune response to $S$. uberis have focused on humoral immunity. However, a few observations point to a role of cellmediated immunity in the control of S. uberis MG infection. Blood lymphocytes of cows protected after vaccination with live $S$. uberis proliferated in vitro when exposed to killed vaccine bacteria (Hill et al., 1994). Spontaneous resolution of infection coincided with a measurable interleukin IL-17A response in the milk of cows experimentally infected with $S$. 
uberis, suggesting the involvement of IL-17A-producing lymphocytes (Tassi et al., 2013). Gamma Interferon (IFN- $\gamma$ ), another cytokine mainly produced by T lymphocytes, is found in the milk of S. uberis-infected quarters (Bannerman et al., 2004). Memory lymphocytes of CD8+ $\mathrm{CD} 45 \mathrm{RO}+$ phenotype proliferating when exposed to $S$. uberis crude antigen extract in the presence of antigen-presenting cells were found in the blood and mammary secretion (dry glands) of most cows, particularly from infected quarters (Denis et al., 2011): CD8 T cell lines derived by exposure to $S$. uberis antigen released IFN- $\gamma$ and had substantial killing activity towards S. uberis in vitro. Immunization of cows by the subcutaneous route with an S. uberis crude extract (twice before drying-off and once before calving) elicited an antibody response, a moderate IL-17A and IFN- $\gamma$ release in blood upon stimulation with antigen, and cells that could exert a cytotoxic activity towards monocytes that had phagocytosed S. uberis (Wedlock et al., 2014). The protective effect of these humoral and cell-mediated immune responses was not determined.

Important questions regarding the immune mechanisms that are efficient in controlling S. uberis mastitis remain unanswered. Is phagocytosis by neutrophils required, and what is the cause of the apparent ineffective opsonophagocytic killing? Is inflammation a beneficial or detrimental response to $S$. uberis infection of the MG? What cell-mediated immune response is best suited to allow the MG to get rid of S. uberis infections? The interaction of S. uberis with the MG remains intriguing in many respects. These uncertainties hamper the development of an effective vaccine.

\section{Streptococcus agalactiae Mastitis Vaccines}

Clinical and subclinical mastitis due to Streptococcus agalactiae are frequent in countries that develop their dairy industry, such as Brazil, China or Portugal (Almeida et al., 2016, Bi et al., 2016, Carvalho-Castro et al., 2017, Pang et al., 2017), and are reemerging in 
countries where dairy farming is developed but farming conditions change as in Northern Europe (Mweu et al., 2012, Lyhs et al., 2016). This situation could rekindle interest in vaccine design after a long period of neglect owing to the effectiveness of conventional control measures in ridding herds of $S$. agalactiae $\mathrm{MG}$ infection and keeping them free from infection (Keefe, 1997, Erskine, 2012).

The development of vaccines to prevent life-threatening infections of human neonates or adults with underlying medical conditions is an active field of medical research (Song et al., 2018), although, currently, no licensed S. agalactiae medical vaccine is available on the market (Lin et al., 2018). Owing to the importance of $S$. agalactiae capsules in the pathogenesis of infections, attempts have primarily targeted capsular polysaccharides to elicit opsonic antibodies by conjugating purified polysaccharides to a protein carrier to enhance their immunogenicity (Baker and Edwards, 2003). Complications are the multiplicity of capsules serotypes (ten are considered in the serotype classification), which are susceptible to change under vaccine pressure, and the cost and complexity of vaccine formulation. Bacterial surface proteins are also used as antigens to elicit a humoral response aiming at improving phagocytosis (Lindahl et al., 2005) and several clinical trials are ongoing (Song et al., 2018). With those antigens, problems come from gene diversity and allelic variability of surface and secreted proteins, mostly related to genomic islands and other mobile genetic elements (Brochet et al., 2006). Besides, the accessibility of surface antigen differs from strain to strain (Maione et al., 2005).

Early attempts to develop efficient vaccines against $S$. agalactiae mastitis relied on bacterins, with variable results. An encouraging outcome was obtained with an autogenous vaccine in combination with antibiotic therapy (Johnson and Norcross, 1971). Another study showed that vaccination or natural infections were not protective despite the induction of circulating strain-specific antibodies (Mackie et al., 1983). More recently, subunit vaccines 
based on purified bacterial components have been assessed. The group B polysaccharide coupled to a protein carrier was shown to elicit opsonic antibodies in immunized cows, but the protective effect was not tested (Rainard, 1992). Streptococcal surface proteins have been the target of several trials, as they are shared by sizable proportions of mastitis isolates. Immunization of cows with the protein $\mathrm{X}$ elicited opsonic antibodies and increased the recruitment and bactericidal activity of neutrophils in milk at the onset of infection (Rainard et al., 1991). Another surface protein shared by most mastitis isolates is the CAMP factor, which induces some protection as a vaccine antigen in a mouse mastitis model (Liu et al., 2017).

These encouraging preliminary studies await their translation to the field. One possible pitfall is the capacity of S. agalactiae strains to modify the expression of their surface antigens, with possible eclipse or loss of capsular and protein production (Jensen, 1980, Rosini et al., 2015). It will probably be necessary to combine several of these antigens to circumvent that issue.

\section{Streptococcus dysgalactiae Mastitis Vaccines}

S. dysgalactiae subspecies dysgalactiae ranks highly among bacteria responsible for clinical and subclinical mastitis (Sampimon et al., 2009, Lundberg et al., 2014, Zhang et al., 2018). The dearth in research on the pathogenesis and immune response to this pathogen, relatively to the extensive research on pathogens of similar importance such as $S$. uberis or $S$. aureus, is surprising (Klaas and Zadoks, 2018). Consequently, we know little about the MG defenses specific to this pathogen. In an early vaccine trial, formalin-killed bacteria were administered by the subcutaneous route in the region of the supramammary lymph node (Stark and Norcross, 1970). Repeated, frequent immunizations were necessary to get partial protection which was attributed to the elicited antibodies. Recently, several groups used the dehydrogenase and protein receptor GapC as vaccine antigen. In a dry cow model, vaccination with GapC 
575

576

577

reduced the challenge-induced inflammation as assessed by the concentrations of cells in the MG secretion (Bolton et al., 2004). This preliminary study was not continued. A chimeric protein comprising S. dysgalactiae GapC and two S. aureus proteins (IsdB and TRAP) elicited protection in a mouse lethal challenge after two vaccine injections, the first in complete Freund adjuvant, the second in incomplete Freund adjuvant (Yu et al., 2014). One asset of GapC is that this protein shows a high sequence identity across several bacterial species so that crossprotection can be expected. Indeed, cross-protection was obtained by immunizing mice with a genetically modified E. coli expressing S. dysgalactiae GapC (11-150 sequence) in a lethal mouse challenge with either S. dysgalactiae, S. uberis or S. agalactiae (1.5 to $2 \times 10^{9} \mathrm{CFU}$ by intraperitoneal injection) (Song et al., 2017). Translation to the cow will need challenges less distant from natural infection of the MG. GapC-induced cross-protection is not systematic, as immunization of cows with recombinant S. uberis GapC did not protect against challenges with S. dysgalactiae (Fontaine et al., 2002). Another potential asset of $\mathrm{GapC}$ is that it elicits specific CD4+ T cell immune responses preferentially towards Th1/Th17 polarization (Yao et al., 2016). This line of research is worth pursuing.

\section{Staphylococcus aureus VACCINES}

\section{Whole-bacterial Cell Vaccines}

Despite the implementation of the standard mastitis prevention program, S. aureus mastitis remains endemic in most countries and is the most frequent cause of subclinical mastitis of dairy cows in many regions (Omore et al., 1996, Petzer et al., 2009, Kalmus et al., 2011, Mistry et al., 2016, Poutrel et al., 2018). Mastitis by S. aureus remains a major problem to the dairy industry owing to its contagiousness, persistence in infected glands, resistance to treatment and threat to public health (Rainard et al., 2018). The development of an efficacious vaccine has long been a research target. Some success has been achieved with bacterins combined with 
detoxified staphylococcal toxins (formalin-treated culture supernate) to prevent the most severe forms of mastitis of small ruminants (Derbyshire and Smith, 1969). This result can be considered acceptable as the prevalence of $S$. aureus in small ruminant herds is usually limited and the main issue is with severe, often gangrenous mastitis (Bergonier and Berthelot, 2003, Contreras et al., 2003, Gelasakis et al., 2015). In cows, S. aureus mastitis is usually subclinical, so what is expected of an efficient vaccine is to reduce the incidence of new infections and limit their spread within herds (Middleton, 2008). As most infections persist over long periods, another indication would be the elimination of chronic infections. The results obtained with bacterin plus toxoids have been inconsistent (Slanetz et al., 1965, Brock et al., 1975). The addition of toxoids to killed bacteria was necessary to obtain the best protection (Derbyshire, 1960). In this regard, several studies have suggested that the alpha and beta toxins are involved in the pathogenesis of mastitis (Bramley and Neave, 1975, Yancey, 1993). An improvement over this first approach has been sought by taking into consideration the production of bacterial antigens during infection. Live vaccines confer better protection than do killed vaccines, an edge that was attributed to the production of "in vivo antigens" and to the elicitation of antibodies in the IgG2 isotype (Watson, 1981). In addition, the live vaccine boosted the recruitment of neutrophils into the MG during the initiation phase of the inflammatory response (Colditz and Watson, 1982). A preparation of bacteria grown under suitable in vitro conditions stimulating the production of a pseudocapsule or slime, administered by the systemic (subcutaneous) route with an appropriate adjuvant favoring the production of antibodies in the $\mathrm{IgG}_{2}$ isotype (dextran sulfate), was proposed as a strategy to get protection (Watson, 1992a). The live vaccine lead has recently been refined by engineering a defective VraG mutant in a genetically stable small colony variant (SCV) S. aureus (Côté-Gravel et al., 2016). SCVs have altered metabolism and slow growth, associated with reduced production of toxins but increased capacity to invade, survive and hide within epithelial cells compared to their parent strains 
(Atalla et al., 2011). It has been proposed that SCVs are associated with chronic infections of the MG, and shown that they induce in cows immune responses different from those induced by parent strains (Atalla et al., 2010). Strongly expressed by S. aureus during mastitis, VraG encodes a putative $\mathrm{ABC}$ transporter that could be required for cationic antimicrobial peptide sensing and resistance (Allard et al., 2013). The resulting virulence-attenuated mutant induced a marked antibody response cross-reacting with a variety of mastitis $S$. aureus isolates in mice when administered as a live vaccine by the subcutaneous route (Côté-Gravel et al., 2016). Besides antibodies, the live-attenuated vaccine elicited a cell-mediated response characterized by the induction of splenocytes secreting IFN- $\gamma$ and IL-17, contrary to a bacterin combined or not with inactivated E. coli J5 (Côté-Gravel et al., 2019). These studies in mice prompt further research and translation to ruminants. The SCV formation provides the possibility of delivering antigens in the host cell cytoplasmic compartment, which could modify the orientation of the cell-mediated immune response (Côté-Gravel et al., 2019).

The "in vivo antigen" approach was patented (Watson, 1992a) but has not find a way into widespread commercialization. Another patented bacterin vaccine preparation, comprising three S. aureus strains grown in a medium favoring the production of exopolysaccharides, showed encouraging results in a small-scale experiment, but without published follow-up (Leitner et al., 2003). More recently, the "slime track" has been followed and developed (Pérez et al., 2009). The production of exopolysaccharides by S. aureus mastitis isolates is inducible by growth in special laboratory media rich in salt and sugars or in milk whey (Baselga et al., 1994). Among these exopolysaccharides there are true capsular polysaccharides, which form thin and discontinuous microcapsules of mainly two serotypes, CP5 and CP8 (Sutra et al., 1990a, Poutrel and Sutra, 1993), with a variable expression between strains and within bacterial populations of most mastitis isolates (Poutrel et al., 1997). Specific antibodies can be elicited by immunizing cows with capsular polysaccharides conjugated to a protein carrier (Gilbert et 
al., 1994, Lee et al., 2005). The anti-capsular antibodies are opsonic (Kampen et al., 2005) but are not required to opsonize mastitis isolates. Moreover, a number of isolates from chronic infections do not produce capsules because they repress their production or have mutated in the capsule operon (Tuchscherr et al., 2005). Those nontypable variants or mutants are supposed to have an increased capacity to adhere to and invade epithelial cells than their capsulated counterparts (Tuchscherr et al., 2010). On the other hand, the growth of mastitis isolates in exopolysaccharide-promoting media interferes with phagocytosis by neutrophils (Sutra et al., 1990b). Apart from capsular polysaccharides, the contribution of inducible slime is likely. Bacterins comprising strong slime-producing S. aureus induce antibodies against poly-Nacetyl- $\beta$-glucosamine (PNAG), a major component of slime, and have conferred protection of lactating ewes against infection and mastitis (Pérez et al., 2009). Bacterins were better inducers of antibodies to PNAG than was purified slime, even when slime was incorporated into liposomes. After an intramammary challenge with a live heterologous $S$. aureus strain, the shedding of bacteria was reduced by two orders of magnitude in the groups vaccinated with the high slime-producing bacteria compared to controls and animals in the groups vaccinated with the low slime-producing bacteria. Surprisingly, bacterial concentrations in the milk of ewes immunized with crude or purified PNAG exceeded concentrations in milk of control ewes. Clinical data and mammary tissue lesions tended to correlate negatively with the antibody titers and bacterial shedding reduction in milk (Pérez et al., 2009). Accordingly, antibodies induced by the deacylated form of PNAG (dPNAG) arre opsonic (Maira-Litran et al., 2005). The study suggests that antibodies to slime, including PNAG, are induced when associated with bacterial bodies, and that they protect against, or correlate with protection to, severe mastitis in ewes. This protection manifested itself by a marked reduction in the severity of the symptoms. It should be noted, however, that not all mastitis isolates are high producers of slime (Oliveira et al., 2006, Vautor et al., 2008, Dhanawade et al., 2010). The slime vaccine approach was pursued 
675

676

677

678

679

680

681

682

683

684

685

686

687

688

689

690

691

692

693

694

695

696

697

698

699

in a trial involving cows that were vaccinated with S. aureus bacterins with either high or low slime content (Prenafeta et al., 2010). Two doses of bacterins were administered 45 days apart to primiparous gestating cows before calving, followed by an intramammary challenge with a heterologous strain of S. aureus. Compared to unvaccinated heifers, only those vaccinated with the high slime-producing bacterin shed less colony-forming units (CFU) of bacteria in their milk on day 1 post-challenge, but there was no difference in clinical signs between groups. Antibodies to slime were associated with the reduction in milk CFU numbers. This line of

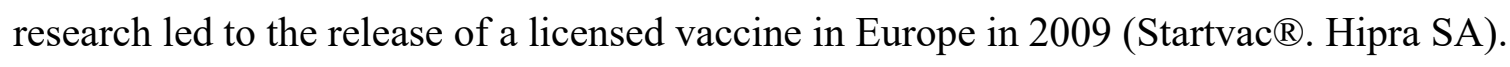

A field study was conducted in two large dairy herds by using the StartVac ${ }^{\circledR}$ vaccine according to the label directions (Schukken et al., 2014). Cows received three doses of the vaccine, at 45 days before the expected parturition date, 35 days later, and at 52 days in milk. The vaccine consists of killed E. coli J5 bacteria and killed S. aureus slime-producing strain SP140 emulsified in liquid paraffin. It is administered by the intramuscular route. Over the 21-month observation period, vaccination resulted in a moderate reduction in the incidence of new staphylococcal IMI, and complex modeling of the IMI dynamics yielded a reduction of the "basic reproduction ratio" of $45 \%$ for S. aureus and $35 \%$ for coagulase-negative staphylococci. In a field study involving seven farms, the vaccine administered following the label regimen did not reduce the incidence or prevalence of clinical or subclinical mastitis but was associated with a significant reduction in the severity of clinical cases and milk losses, with a return on investment of 2.57 to 1 (Bradley et al., 2015). In that study, most clinical cases (25\%) were due to E. coli, clinical cases caused by S. aureus or coagulase-negative staphylococci CoNS accounting for only 2.5 and 5.6\% of cases, respectively. Another field study conducted in two large farms in which S. aureus mastitis prevalence was high did not show any beneficial effect on udder health, milk production or culling rate (Landin et al., 2015). Another trial carried out in a herd in which S. aureus was the predominant pathogen led the 
authors to conclude that the vaccine was not an appropriate tool to manage the S. aureus problem (Freick et al., 2016).

These discrepant results can be compared to the efficacy assessment of another vaccine licensed in Northern America, the Lysigin ${ }^{\circledR}$ vaccine (Boehringer Ingelheim Vetmedica, Inc.). The vaccine is composed of a lysate of one serotype 5 , two serotype 8 and two nontypable ("serotype 336", not a capsular polysaccharide but probably cell wall teichoic acid (Verdier et al., 2007)) strains (Ma et al., 2004), administered by the subcutaneous route with an alum-based proprietary adjuvant. Lysigin vaccine efficacy has been evaluated in several studies, with variable results showing a decreased clinical severity of mastitis, lower milk SCC, sometimes a reduction in the incidence of IMI (reviewed in (Middleton, 2008)). However, unfavorable results were also obtained, as in a study with heifers vaccinated twice in late gestation, in which the only positive effect of the vaccine was a reduction in the duration of clinical mastitis after challenge (Middleton et al., 2006). A subsequent field study by the same group did not show a reduction in the prevalence or incidence of S. aureus or CoNS IMI by the Lysigin ${ }^{\circledR}$ vaccine (Middleton et al., 2009).

\section{Subunit Vaccines}

Overall, the commercial vaccines against $S$. aureus mastitis tend to reduce the severity of clinical mastitis but do not solve the issue of chronic subclinical mastitis. The current bacterin vaccines are not very different from the vaccine approach advocated by Dennis Watson (Watson, 1992a). Many other attempts to improve on these vaccines have been based on the use of bacterial components supposed to play a role in the pathogenesis or to be the target of efficient immune defenses of the host (Scali et al., 2015). An early attempt was the evaluation of staphylococcal protein A to protect cows from repeated exposure to S. aureus by dipping the teats in a bacterial suspension immediately after milking (Pankey et al., 1985). Vaccinated and 
control cows had a similar incidence of $S$. aureus mastitis and milk production, but the vaccine improved the spontaneous cure rate of IMI. However, the definition of infection was based on only one positive diagnostic, which is not sufficient to define an established infection, even more so if we consider that transient colonization of the teat canal by S. aureus is likely to have occurred bearing in mind the challenge procedure.

Staphylococcus aureus is well equipped to adhere to epithelial cells, thanks to the regulated expression of a number of redundant adhesins (Foster and Hook, 1998). Among the adhesins that are likely to contribute to adhesion and invasion, Fibronectin-binding proteins (FnBPA and FnBPB) are important contributors (Brouillette et al., 2004). Immunization with FnBP, collagen-binding protein, or clumping factor usually decreased the severity of mastitis induced by intramammary challenges (Mamo et al., 1995, Mamo et al., 2000, Hu et al., 2010). These studies were conducted in murine mastitis models, and their translation to the cow remains to be performed. A DNA vaccine based on a plasmid encoding the bovine granulocytemacrophage - colony-stimulating factor (GM-CSF) and the S. aureus FnBP and clumping factor A (ClfA) genes was used to vaccinate heifers twice before a final booster injection of the two recombinant S. aureus proteins (Shkreta et al., 2004). The intramammary challenge with S. aureus Newbould 305 was carried out in three quarters of vaccinated $(n=4)$ and control $(n=$ 4) cows three weeks after calving. The vaccine elicited antibodies and lymphoproliferative responses, with partial protection illustrated by a reduced bacterial shedding and an increased cure rate in the vaccinated animals (Shkreta et al., 2004). These encouraging results await confirmation on a larger scale.

The capacity to acquire iron or growth in milk is an important attribute of mastitisassociated bacteria. The expression of several S. aureus iron-regulated genes is upregulated during growth in vivo (Allard et al., 2006). Among these genes, those of the iron-regulated surface determinants (Isd) system (IsdABSDEFGHI) are specialized in the acquisition of iron 
from the heme proteins (Skaar and Schneewind, 2004). Cattle immunization with IsdB and IsdH induced strong antibody responses and proliferation of CD4+ but not CD8+ cells in a PBMC stimulation assay (Ster et al., 2010). Protection in cattle induced by these antigens has not been established.

Other shared antigens have been identified as vaccine antigen candidates. Two proteins with homology to glyceraldehyde-3-phosphate dehydrogenase, GapB and GapC, have highly conserved sequences and are shared by mastitis-associated S. aureus (Goji et al., 2004). DNA vaccination with plasmids encoding the GapC and GapB proteins boosted with recombinant proteins induced humoral and cellular immune responses in mice, but protection was not tested (Kerro-Dego et al., 2006). Research is ongoing to optimize the production of neutralizing antibodies in the MG to S. aureus immune evasion proteins such as adhesins or leukotoxins by combining adjuvants and selecting the most appropriate site of injection (Boerhout et al., 2015, Boerhout et al., 2018, Misra et al., 2018). An overview of the main S. aureus vaccine trials is given in Table 2 .

The general picture emerging from these numerous S. aureus vaccine trials, and still more numerous not cited here due to redundancy and space constraints, is one of encouraging perspectives followed by aborted development. The few vaccines that reached licensing and field use so far are based on killed whole cell bacteria and have had mixed results. All researchers agreed that there is ample room for improvement.

\section{CONCLUSIONS}

This review aims at giving an objective account of the present state of mastitis vaccines and current research. It is clear that the achievements are not up to expectations, whatever the bacteria involved. There are several obstacles to the development of efficacious vaccines against mammary pathogens. Some result from the MG physiology, particularly in lactation, as 
dairy cows have been selected to secrete large amounts of milk which blunts and waters down immune defenses. Others pertain to the pathogens, such as their diversity and their adaptation to the MG niche. The complexities of the host-pathogen interaction within the cow's MG represent another major obstacle to the development of efficacious mastitis vaccines of the hostpathogen interaction within the cow's mammary gland represent a major obstacle to the development of efficacious mastitis vaccines. These difficulties may be confounded by a possible misdirection of most of past research, biased towards antibody-dependent defenses (Figure 2). There is a need for an in-depth analysis of the reasons that could explain the lack of success of past attempts, with a view to proposing new ways of getting out of the mastitis vaccine predicament. One way is to explore how cell-mediated immunity could strengthen MG defenses, and how this immunity could be harnessed by vaccination. Eliciting type 3 immunity in the MG is an attractive option (Rainard et al., 2020). It will be useful to select adjuvants that orient the immune response towards protection and to validate reliable correlates of protection. The route of administration is also likely to be of major importance. In addition, lessons learned from successes and failures of vaccines directed at other diseases could help identify the peculiarities of the MG niche and the different ways bacteria cause mastitis, hence helping to focus on relevant vaccine targets.

There have been a number of attempts to follow new research leads that have already yielded some promising results, but much attention has been paid to the choice of antigens and adjuvant (vaccinology) and little to the induced immune response (immunology). Doubts about vaccination have been expressed due to the numerous failures and misleading claims of success. In our opinion, there is no unsurmontable obstacle to the development of efficacious mastitis vaccines. Nonetheless, lessons must be learned from past attempts, a frank appraisal of current achievements made and new approaches boldly adopted. Then a much greater chance of success will arise. 


\section{Acknowledgments}

803

804

805

806

807

808

809

810

811

812

813

814

815

816

817

818

The authors are grateful to many colleagues for the fruitful discussions and exchanges over the past years. We apologize to all the researchers whose studies we could not mention due to space limitations. We also had to make choices for the sake of clarity, as there have been so many studies in the field covered by our review. We hope that our blindspots have not hampered the pertinence of our findings and conclusions. The authors have not stated any conflict of interests.

\section{REFERENCES}

Allard, M., H. Moisan, E. Brouillette, A. L. Gervais, M. Jacques, P. Lacasse, M. S. Diarra, and F. Malouin. 2006. Transcriptional modulation of some Staphylococcus aureus iron-regulated genes during growth in vitro and in a tissue cage model in vivo. Microbes Infect. 8(7):1679-1690.

Allard, M., C. Ster, C. L. Jacob, D. Scholl, M. S. Diarra, P. Lacasse, and F. Malouin. 2013. The expression of a putative exotoxin and an $A B C$ transporter during bovine intramammary infection contributes to the virulence of Staphylococcus aureus. Vet. Microbiol. 162(2-4):761-770.

Almeida, A., C. Alves-Barroco, E. Sauvage, R. Bexiga, P. Albuquerque, F. Tavares, I. SantosSanches, and P. Glaser. 2016. Persistence of a dominant bovine lineage of group B Streptococcus reveals genomic signatures of host adaptation. Environ. Microbiol. 18(11):4216-4229.

Almeida, R. A., O. K. Dego, S. I. Headrick, M. J. Lewis, and S. P. Oliver. 2015. Role of Streptococcus uberis adhesion molecule in the pathogenesis of Streptococcus uberis mastitis. Vet. Microbiol. 179(3-4):332-335.

Almeida, R. A., D. A. Luther, H. M. Park, and S. P. Oliver. 2006. Identification, isolation, and partial characterization of a novel Streptococcus uberis adhesion molecule (SUAM). Vet. Microbiol. 115(1-3):183-191. 
Almeida, R. A. and S. P. Oliver. 1993. Antiphagocytic Effect of the Capsule of Streptococcus uberis. J. Vet. Med. Series B 40(9-10):707-714.

Archer, N., S. A. Egan, T. J. Coffey, R. D. Emes, M. F. Addis, P. N. Ward, A. M. Blanchard, and J. A. Leigh. 2020. A Paradox in Bacterial Pathogenesis: Activation of the Local Macrophage Inflammasome Is Required for Virulence of Streptococcus uberis. Pathogens 9(12):997.

Atalla, H., C. Gyles, and B. Mallard. 2011. Staphylococcus aureus small colony variants (SCVs) and their role in disease. Anim Health Res. Rev. 12(1):33-45.

Atalla, H., B. Wilkie, C. Gyles, K. Leslie, L. Mutharia, and B. Mallard. 2010. Antibody and cellmediated immune responses to Staphylococcus aureus small colony variants and their parental strains associated with bovine mastitis. Dev. Comp. Immunol. 34(12):1283-1290.

Baker, C. J. and M. S. Edwards. 2003. Group B streptococcal conjugate vaccines. Arch. Dis. Child. 88(5):375-378.

Bannerman, D. D., M. J. Paape, J. P. Goff, K. Kimura, J. D. Lippolis, and J. C. Hope. 2004. Innate immune response to intramammary infection with Serratia marcescens and Streptococcus uberis. Vet. Res. 35(6):681-700.

Baselga, R., I. Albizu, and B. Amorena. 1994. Staphylococcus aureus capsule and slime as virulence factors in ruminant mastitis. A review. Vet. Microbiol. 39(3-4):195-204.

Baumgartner, J. D. and M. P. Glauser. 1993. Immunotherapy of Endotoxemia and Septicemia. Immunobiol. 187(3-5):464-477.

Baumgartner, J. D., D. Heumann, T. Calandra, and M. P. Glauser. 1991. Antibodies to lipopolysaccharides after immunization of humans with the rough mutant Escherichia coli J5. J. Infect. Dis. 163(4):769-772.

Bergonier, D. and X. Berthelot. 2003. New advances in epizootiology and control of ewe mastitis. Livestock Prod. Sci. 79(1):1-16.

Bi, Y., Y. J. Wang, Y. Qin, R. Guix Vallverdu, J. Maldonado Garcia, W. Sun, S. Li, and Z. Cao. 2016. Prevalence of Bovine Mastitis Pathogens in Bulk Tank Milk in China. PLoS ONE 11(5):e0155621.

Blum, S. E., R. J. Goldstone, J. P. R. Connolly, M. Reperant-Ferter, P. Germon, N. F. Inglis, O. Krifucks, S. Mathur, E. Manson, K. McLean, P. Rainard, A. J. Roe, G. Leitner, and D. G. E. Smith. 2018. Postgenomics Characterization of an Essential Genetic Determinant of Mammary Pathogenic Escherichia coli. MBio 9(2).

Boerhout, E., M. Vrieling, L. Benedictus, I. Daemen, L. Ravesloot, V. Rutten, P. Nuijten, J. van Strijp, A. Koets, and S. Eisenberg. 2015. Immunization routes in cattle impact the levels and neutralizing capacity of antibodies induced against S. aureus immune evasion proteins. Vet. Res. 46(1):115. 
Boerhout, E. M., A. P. Koets, T. G. T. Mols-Vorstermans, P. J. M. Nuijten, M. J. H. Hoeijmakers, V. Rutten, and J. J. E. Bijlsma. 2018. The antibody response in the bovine mammary gland is influenced by the adjuvant and the site of subcutaneous vaccination. Vet. Res. 49(1):25.

Bolton, A., X. M. Song, P. Willson, M. C. Fontaine, A. A. Potter, and J. Perez-Casal. 2004. Use of the surface proteins GapC and Mig of Streptococcus dysgalactiae as potential protective antigens against bovine mastitis. Can. J. Microbiol. 50(6):423-432.

Brade, L., S. Hensen, and H. Brade. 2013. Evaluation of a LPS-based glycoconjugate vaccine against bovine Escherichia coli mastitis: Formation of LPS Abs in cows after immunization with E. coli core oligosaccharides conjugated to hemocyanine. Innate immunity 19(4):368-377.

Bradley, A. J., J. E. Breen, B. Payne, V. White, and M. J. Green. 2015. An investigation of the efficacy of a polyvalent mastitis vaccine using different vaccination regimens under field conditions in the United Kingdom. J. Dairy Sci. 98(3):1706-1720.

Bradley, A. J., J. E. Breen, B. Payne, P. Williams, and M. J. Green. 2010. The use of a cephalonium containing dry cow therapy and an internal teat sealant, both alone and in combination. J. Dairy Sci. 93(4):1566-1577.

Bramley, A. J. and F. K. Neave. 1975. Studies on the control of coliform mastitis in dairy cows. Br. Vet. J. 131(2):160-169.

Braun, V. 1997. Surface signaling: Novel transcription initiation mechanism starting from the cell surface. Arch. Microbiol. 167(6):325-331.

Brochet, M., E. Couve, M. Zouine, T. Vallaeys, C. Rusniok, M. C. Lamy, C. Buchrieser, P. TrieuCuot, F. Kunst, C. Poyart, and P. Glaser. 2006. Genomic diversity and evolution within the species Streptococcus agalactiae. Microbes Infect. 8(5):1227-1243.

Brock, J. H., E. D. Steel, and B. Reiter. 1975. The effect of intramuscular and intramammary vaccination of cows on antibody levels and resistance to intramammary infection by Staphylococcus aureus. Res. Vet. Sci. 19(2):152-158.

Brouillette, E., G. Grondin, C. Lefebvre, B. G. Talbot, and F. Malouin. 2004. Mouse mastitis model of infection for antimicrobial compound efficacy studies against intracellular and extracellular forms of Staphylococcus aureus. Vet. Microbiol. 101(4):253-262.

Carvalho-Castro, G. A., J. R. Silva, L. V. Paiva, D. A. C. Custodioa, R. O. Moreira, G. F. Mian, I. A. Prado, A. Chalfun, and G. M. Costa. 2017. Molecular epidemiology of Streptococcus agalactiae isolated from mastitis in Brazilian dairy herds. Braz. J. Microbiol. 48(3):551-559.

Cebron, N., S. Maman, S. Walachowski, B. Gausseres, P. Cunha, P. Rainard, and G. Foucras. 2020. Mammary Th17-related immunity, but not high systemic Th1 response is associated with protection against E. coli mastitis. NPJ Vaccines 5(1):108. 
Chaiyotwittayakun, A., J. L. Burton, P. S. Weber, K. Kizilkaya, F. F. Cardoso, and R. J. Erskine. 2004. Hyperimmunization of steers with J5 Escherichia coli bacterin: effects on isotype-specific serum antibody responses and cross reactivity with heterogeneous Gram-negative bacteria. J. Dairy Sci. 87(10):3375-3385.

Colditz, I. G. and D. L. Watson. 1982. Effect of immunisation on the early influx of neutrophils during staphylococcal mastitis in ewes. Res. Vet. Sci. 33(2):146-151.

Collado, R., C. Montbrau, M. Sitja, and A. Prenafeta. 2018. Study of the efficacy of a Streptococcus uberis mastitis vaccine against an experimental intramammary infection with a heterologous strain in dairy cows. J. Dairy Sci. 101(11):10290-10302.

Contreras, A., C. Luengo, A. Sanchez, and J. C. Corrales. 2003. The role of intramammary pathogens in dairy goats. Livestock Product.Sci. 79:273-283.

Côté-Gravel, J., E. Brouillette, and F. Malouin. 2019. Vaccination with a live-attenuated smallcolony variant improves the humoral and cell-mediated responses against Staphylococcus aureus. PLOS ONE 14(12):e0227109.

Côté-Gravel, J., E. Brouillette, N. Obradovic, C. Ster, B. G. Talbot, and F. Malouin. 2016. Characterization of a vraG Mutant in a Genetically Stable Staphylococcus aureus Small-Colony Variant and Preliminary Assessment for Use as a Live-Attenuated Vaccine against Intrammamary Infections. PLOS ONE 11(11):e0166621.

Craven, N. and M. R. Williams. 1985. Defences of the bovine mammary gland against infection and prospects for their enhancement. Vet. Immunol. Immunopathol. 10(1):71-127.

Cross, A. S. 2014. Anti-endotoxin vaccines: back to the future. Virulence 5(1):219-225.

Cross, A. S., H. J. Karreman, L. Zhang, Z. Rosenberg, S. M. Opal, and A. Lees. 2014. Immunization of cows with novel core glycolipid vaccine induces anti-endotoxin antibodies in bovine colostrum. Vaccine 32(46):6107-6114.

Crowley, R. C., J. A. Leigh, P. N. Ward, H. M. Lappin-Scott, and L. D. Bowler. 2011. Differential Protein Expression in Streptococcus uberis under Planktonic and Biofilm Growth Conditions. Appl. Environ. Microbiol. 77(1):382-384.

Cullor, J. S. 1991. The Escherichia coli J5 vaccine: investigating a new tool to combat coliform mastitis. Veterinary Medicine 86(8):836-844.

Cunningham, M. W. 2000. Pathogenesis of group A streptococcal infections. Clin. Microbiol. Rev. 13(3):470-511.

De Cueninck, B. J. 1979. Immune-mediated inflammation in the lumen of the bovine mammary gland. Int. Arch. Allergy Appl. Immunol. 59(4):394-402.

DeGraves, F. J. and J. Fetrow. 1991. Partial budget analysis of vaccinating dairy cattle against coliform mastitis with an Escherichia coli J5 vaccine. J. Am. Vet. Med. Assoc. 199(4):451-455. 

Streptococcus uberis-specific T cells are present in mammary gland secretions of cows and can be activated to kill. Vet. Res. Commun. 35(3):145-156.

Denis, M., N. A. Parlane, S. J. Lacy-Hulbert, E. L. Summers, B. M. Buddle, and D. N. Wedlock. 2006. Bactericidal activity of macrophages against Streptococcus uberis is different in mammary gland secretions of lactating and drying off cows. Vet. Immunol. Immunopathol. 114(1-2):111-120.

Denis, M., D. N. Wedlock, S. J. Lacy-Hulbert, J. E. Hillerton, and B. M. Buddle. 2009. Vaccines against bovine mastitis in the New Zealand context: what is the best way forward? New Zealand Vet. J. $57(3): 132-140$.

Derbyshire, J. B. 1960. Studies in immunity to experimental staphylococcal mastitis in the goat and cow. J. Comp. Pathol. 70:222-231.

Derbyshire, J. B. and G. S. Smith. 1969. Immunization against experimental staphylococcal mastitis in the goat by the intramammary infusion of cell-toxoid vaccine. Res. Vet. Sci. 10(6):559-564. Dhanawade, N. B., D. R. Kalorey, R. Srinivasan, S. B. Barbuddhe, and N. V. Kurkure. 2010. Detection of intercellular adhesion genes and biofilm production in Staphylococcus aureus isolated from bovine subclinical mastitis. Vet. Res. Commun. 34(1):81-89.

Dieser, S. A., A. S. Fessia, M. P. Ferrari, C. G. Raspanti, and L. M. Odierno. 2017. Streptococcus uberis: In vitro biofilm production in response to carbohydrates and skim milk. Rev. Argent. Microbiol. 49(4):305-310.

Ditcham, W. G., J. A. Leigh, A. P. Bland, and A. W. Hill. 1996. Adhesion of Streptococcus uberis to monolayers of cultured epithelial cells derived from the bovine mammary gland. FEMS Immunol. Med. Microbiol. 14(2-3):145-150.

Dogan, B., M. Rishniw, G. Bruant, J. Harel, Y. H. Schukken, and K. W. Simpson. 2012. Phylogroup and IpfA influence epithelial invasion by mastitis associated Escherichia coli. Vet. Microbiol. 159(1-2):163-170.

Dosogne, H., F. Vangroenweghe, and C. Burvenich. 2002. Potential mechanism of action of J5 vaccine in protection against severe bovine coliform mastitis. Vet. Res. 33(1):1-12.

Erskine, R. J. 2012. Vaccination strategies for mastitis. Vet. Clin. North Am. Food Anim. Pract. 28(2):257-270.

Erskine, R. J., E. J. VanDyk, P. C. Bartlett, J. L. Burton, and M. C. Boyle. 2007. Effect of hyperimmunization with an Escherichia coli J5 bacterin in adult lactating dairy cows. J. Am. Vet. Med. Assoc. 231(7):1092-1097.

Field, T. R., P. N. Ward, L. H. Pedersen, and J. A. Leigh. 2003. The hyaluronic acid capsule of Streptococcus uberis is not required for the development of infection and clinical mastitis. Infect. Immun. 71(1):132-139. 
Finch, J. M., A. W. Hill, T. R. Field, and J. A. Leigh. 1994. Local vaccination with killed

967

968

969

970

971

972

973

974

975

976

977

978

979

980

981

982

983

984

985

986

987

988

989

990

991

992

993

994

995

996

997

998

999

1000

Streptococcus uberis protects the bovine mammary gland against experimental intramammary challenge with the homologous strain. Infect. Immun. 62(9):3599-3603.

Finch, J. M., A. Winter, A. W. Walton, and J. A. Leigh. 1997. Further studies on the efficacy of a live vaccine against mastitis caused by Streptococcus uberis. Vaccine 15(10):1138-1143.

Fontaine, M. C., J. Perez-Casal, X. M. Song, J. Shelford, P. J. Willson, and A. A. Potter. 2002. Immunisation of dairy cattle with recombinant Streptococcus uberis GapC or a chimeric CAMP antigen confers protection against heterologous bacterial challenge. Vaccine 20(17-18):2278-2286.

Foster, T. J. and M. Hook. 1998. Surface protein adhesins of Staphylococcus aureus. Trends Microbiol. 6(12):484-488.

Freick, M., Y. Frank, K. Steinert, A. Hamedy, O. Passarge, and A. Sobiraj. 2016. Mastitis vaccination using a commercial polyvalent vaccine or a herd-specific Staphylococcus aureus vaccine Results of a controlled field trial on a dairy farm. Tieraerztl Prax G N 44(4):219-229.

Garcia, S. N., B. I. Osburn, and J. S. Cullor. 2019. A one health perspective on dairy production and dairy food safety. One Health 7:9.

Garenaux, A., M. Caza, and C. M. Dozois. 2011. The Ins and Outs of siderophore mediated iron uptake by extra-intestinal pathogenic Escherichia coli. Vet. Microbiol. 153(1-2):89-98.

Gaucheron, F. 2005. The minerals of milk. Reprod. Nutr. Dev. 45(4):473-483.

Gelasakis, A. I., V. S. Mavrogianni, I. G. Petridis, N. G. C. Vasileiou, and G. C. Fthenakis. 2015. Mastitis in sheep - The last 10 years and the future of research. Vet. Microbiol. 181(1-2):136-146.

Gilbert, F. B., B. Poutrel, and L. Sutra. 1994. Immunogenicity in cows of Staphylococcus aureus type 5 capsular polysaccharide-ovalbumin conjugate. Vaccine 12(4):369-374.

Goerge, T., M. B. Lorenz, S. van Alen, N. O. Hubner, K. Becker, and R. Kock. 2017. MRSA colonization and infection among persons with occupational livestock exposure in Europe: Prevalence, preventive options and evidence. Vet. Microbiol. 200:6-12.

Goji, N., A. A. Potter, and J. Perez-Casal. 2004. Characterization of two proteins of Staphylococcus aureus isolated from bovine clinical mastitis with homology to glyceraldehyde-3phosphate dehydrogenase. Vet. Microbiol. 99(3-4):269-279.

Goldstone, R. J., S. Harris, and D. G. Smith. 2016. Genomic content typifying a prevalent clade of bovine mastitis-associated Escherichia coli. Sci. Rep. 6:30115.

Gonzalez, R. N., J. S. Cullor, D. E. Jasper, T. B. Farver, R. B. Bushnell, and M. N. Oliver. 1989. Prevention of clinical coliform mastitis in dairy cows by a mutant Escherichia coli vaccine. Can. J. Vet. Res. 53(3):301-305.

Gorden, P. J., M. D. Kleinhenz, J. A. Ydstie, T. A. Brick, L. M. Slinden, M. P. Peterson, D. E. Straub, and D. T. Burkhardt. 2018. Efficacy of vaccination with a Klebsiella pneumoniae siderophore 
1001

1002

1003

1004

1005

1006

1007

1008

1009

1010

1011

1012

1013

1014

1015

1016

1017

1018

1019

1020

1021

1022

1023

1024

1025

1026

1027

1028

1029

1030

1031

1032

1033

1034

1035

receptor protein vaccine for reduction of Klebsiella mastitis in lactating cattle. J. Dairy Sci. 101(11):10398-10408.

Grant, R. G. and J. M. Finch. 1996. Phagocytosis of Streptococcus uberis by bovine mammary gland macrophages. Res.Vet.Sci. 62(1):74-78.

Green, M. J. and A. J. Bradley. 2013. The changing face of mastitis control. Vet. Rec. 173:517521.

Greisman, S. E. and C. A. Johnston. 1997. Evidence against the hypothesis that antibodies to the inner core of lipopolysaccharides in antisera raised by immunization with enterobacterial deeprough mutants confer broad-spectrum protection during Gram-negative bacterial sepsis. J. Endotoxin Res. 4(2):123-153.

Herry, V., C. Gitton, G. Tabouret, M. Reperant, L. Forge, C. Tasca, F. B. Gilbert, E. Guitton, C. Barc, C. Staub, D. G. E. Smith, P. Germon, G. Foucras, and P. Rainard. 2017. Local immunization impacts the response of dairy cows to Escherichia coli mastitis. Sci. Rep. 7(1):3441.

Hill, A. W. 1988. Pathogenicity of two strains of Streptococcus uberis infused into lactating and non-lactating bovine mammary glands. Res. Vet. Sci. 45(3):400-404.

Hill, A. W. 1991. Vaccination of cows with rough Escherichia coli mutants fails to protect against experimental intramammary bacterial challenge. Vet.Res.Commun. 15:7-16.

Hill, A. W., J. M. Finch, T. R. Field, and J. A. Leigh. 1994. Immune modification of the pathogenesis of Streptococcus uberis mastitis in the dairy cow. FEMS Immunol. Med. Microbiol. 8(2):109-117.

Hill, A. W., D. J. Heneghan, T. R. Field, and M. R. Williams. 1983a. Increase in specific opsonic activity in bovine milk following experimental Escherichia coli mastitis. Res.Vet.Sci. 35(2):222-226.

Hill, A. W., D. J. Heneghan, and M. R. Williams. 1983b. The opsonic activity of bovine milk whey for the phagocytosis and killing by neutrophils of encapsulated and non-encapsulated Escherichia coli. Vet. Microbiol. 8(3):293-300.

Hogan, J. S., V. B. Cannon, K. L. Smith, C. Rinehart, and S. Miller. 2005. Effects of adjuvants on safety and efficacy of an Escherichia coli J5 bacterin. J. Dairy Sci. 88(2):534-542.

Hogan, J. S., K. L. Smith, D. A. Todhunter, and P. S. Schoenberger. 1992a. Field trial to determine efficacy of an Escherichia coli J5 mastitis vaccine. J. Dairy Sci. 75(1):78-84.

Hogan, J. S., D. A. Todhunter, G. M. Tomita, K. L. Smith, and P. S. Schoenberger. 1992b. Opsonic activity of bovine serum and mammary secretion after Escherichia coli J5 vaccination. J. Dairy Sci. 75(1):72-77.

Hogan, J. S., W. P. Weiss, K. L. Smith, D. A. Todhunter, P. S. Schoenberger, and L. M. Sordillo. 1995. Effects of an Escherichia coli J5 vaccine on mild clinical coliform mastitis. J. Dairy Sci. 78(2):285290. 

of an Escherichia coli J5 mastitis vaccine in an experimental challenge trial. J. Dairy Sci. 75(2):415-422. Hogeveen, H., K. Huijps, and T. J. Lam. 2011. Economic aspects of mastitis: new developments. New Zealand Vet. J. 59(1):16-23.

Hu, C. M., R. Gong, A. Z. Guo, and H. C. Chen. 2010. Protective effect of ligand-binding domain of fibronectin-binding protein on mastitis induced by Staphylococcus aureus in mice. Vaccine 28(24):4038-4044.

Jensen, N. E. 1980. Variation of type antigens of group-B streptococci. I. Variation of the Xantigen and of other type antigens in herds where the X-antigen occurs. Acta Vet.Scand. 21(3):367374.

Johnsen, L. B., K. Poulsen, M. Kilian, and T. E. Petersen. 1999. Purification and cloning of a streptokinase from Streptococcus uberis. Infect. Immun. 67(3):1072-1078.

Johnson, S. D. and N. L. Norcross. 1971. An experimental method of vaccination for a Streptococcus agalactiae infected herd. Cornell Vet. 61(2):258-264. 
Leigh, J. A. 2000. Vaccines against bovine mastitis due to Streptococcus uberis current status and future prospects. Adv. Exp. Med. Biol. 480:307-311.

Leigh, J. A. 2002. Immunisation of dairy cattle with recombinant Streptococcus uberis GapC or a chimeric CAMP antigen confers protection against heterologous bacterial challenge M.C. Fontaine et al. Vaccine 20 (2002) 2278-2286. Vaccine 20(25/26):3047-3048.

Leigh, J. A. and T. R. Field. 1991. Killing of Streptococcus uberis by bovine neutrophils following growth in chemically defined media. Vet. Res. Commun. 15(1):1-6.

Leigh, J. A., T. R. Field, and M. R. Williams. 1990. Two strains of Streptococcus uberis, of differing ability to cause clinical mastitis, differ in their ability to resist some host defence factors. Res. Vet. Sci. 49(1):85-87.

Leigh, J. A., J. M. Finch, T. R. Field, N. C. Real, A. Winter, A. W. Walton, and S. M. Hodgkinson. 1999. Vaccination with the plasminogen activator from Streptococcus uberis induces an inhibitory response and protects against experimental infection in the dairy cow. Vaccine 17(7-8):851-857.

Leigh, J. A. and R. A. Lincoln. 1997. Streptococcus uberis acquires plasmin activity following growth in the presence of bovine plasminogen through the action of its specific plasminogen activator. FEMS Microbiol. Lett. 154(1):123-129.

Leitner, G., E. Lubashevsky, A. Glickman, M. Winkler, A. Saran, and Z. Trainin. 2003. Development of a Staphylococcus aureus vaccine against mastitis in dairy cows. I. Challenge trials. Vet. Immunol. Immunopathol. 93(1-2):31-38.

Lin, J., J. S. Hogan, and K. L. Smith. 1999. Growth responses of coliform bacteria to purified immunoglobulin G from cows immunized with ferric enterobactin receptor FepA. J. Dairy Sci. 82(1):86-92.

Lin, S. M., Y. Zhi, K. B. Ahn, S. Lim, and H. S. Seo. 2018. Status of group B streptococcal vaccine development. Clin Exp Vaccine Res 7(1):76-81.

Lindahl, G., M. Stalhammar-Carlemalm, and T. Areschoug. 2005. Surface proteins of Streptococcus agalactiae and related proteins in other bacterial pathogens. Clin. Microbiol. Rev. 18(1):102-127.

Linton, A. H., K. Howe, W. J. Sojka, and C. Wray. 1979. Range of Escherichia-Coli O-Serotypes Causing Clinical Bovine Mastitis and Their Antibiotic-Resistance Spectra. J. Appl. Bacteriol. 46(3):585590.

Linton, A. H. and T. C. Robinson. 1984. Studies on the association of Escherichia coli with bovine mastitis. Br. Vet. J. 140(4):368-373.

Lipman, L. J., A. de Nijs, and W. Gaastra. 1995. Isolation and identification of fimbriae and toxin production by Escherichia coli strains from cows with clinical mastitis. Vet. Microbiol. 47(1-2):1-7. 
Liu, G., J. H. Yin, H. W. Barkema, L. B. Chen, M. Shahid, O. Szenci, J. De Buck, J. P. Kastelic, and B. Han. 2017. Development of a single-dose recombinant CAMP factor entrapping poly(lactide-coglycolide) microspheres-based vaccine against Streptococcus agalactiae. Vaccine 35(9):1246-1253. Lundberg, A.., A. Nyman, H. E. Unnerstad, and K. P. Waller. 2014. Prevalence of bacterial genotypes and outcome of bovine clinical mastitis due to Streptococcus dysgalactiae and Streptococcus uberis. Acta Vet. Scand. 56(1):80.

Lyhs, U., L. Kulkas, J. Katholm, K. P. Waller, K. Saha, R. J. Tomusk, and R. N. Zadoks. 2016. Streptococcus agalactiae Serotype IV in Humans and Cattle, Northern Europe(1). Emerg. Infect. Dis. 22(12):2097-2103.

Ma, J., J. Cocchiaro, and J. C. Lee. 2004. Evaluation of serotypes of Staphylococcus aureus strains used in the production of a bovine mastitis bacterin. J. Dairy Sci. 87(1):178-182.

Mackie, D. P., D. A. Pollock, D. J. Meneely, and E. F. Logan. 1983. Clinical features of consecutive intramammary infections with Streptococcus agalactiae in vaccinated and nonvaccinated heifers. Vet. Rec. 112(20):472-476.

Maione, D., I. Margarit, C. D. Rinaudo, V. Masignani, M. Mora, M. Scarselli, H. Tettelin, C. Brettoni, E. T. Iacobini, R. Rosini, N. D'Agostino, L. Miorin, S. Buccato, M. Mariani, G. Galli, R. Nogarotto, V. Nardi-Dei, F. Vegni, C. Fraser, G. Mancuso, G. Teti, L. C. Madoff, L. C. Paoletti, R. Rappuoli, D. L. Kasper, J. L. Telford, and G. Grandi. 2005. Identification of a universal Group B streptococcus vaccine by multiple genome screen. Science 309(5731):148-150.

Maira-Litran, T., A. Kropec, D. A. Goldmann, and G. B. Pier. 2005. Comparative opsonic and protective activities of Staphylococcus aureus conjugate vaccines containing native or deacetylated Staphylococcal Poly-N-acetyl-beta-(1-6)-glucosamine. Infect. Immun. 73(10):6752-6762.

Mamo, W., G. Froman, and H. P. Muller. 2000. Protection induced in mice vaccinated with recombinant collagen-binding protein (CnBP) and alpha-toxoid against intramammary infection with Staphylococcus aureus. Microbiol. Immunol. 44(5):381-384.

Mamo, W., P. Jonsson, and H. P. Muller. 1995. Opsonization of Staphylococcus aureus with a fibronectin-binding protein antiserum induces protection in mice. Microb. Pathog. 19(1):49-55.

Matthews, K. R., R. A. Almeida, and S. P. Oliver. 1994a. Bovine mammary epithelial cell invasion by Streptococcus uberis. Infect. Immun. 62(12):5641-5646.

Matthews, K. R., B. M. Jayarao, A. J. Guidry, E. F. Erbe, W. P. Wergin, and S. P. Oliver. 1994b. Encapsulation of Streptococcus-Uberis - Influence of Storage and Cultural Conditions. Vet. Microbiol. 39(3-4):361-367.

McClure, A. M., E. E. Christopher, W. A. Wolff, W. H. Fales, G. F. Krause, and J. Miramonti. 1994. Effect of Re-17 mutant Salmonella typhimurium bacterin toxoid on clinical coliform mastitis. J. Dairy Sci. 77(8):2272-2280. 
Middleton, J. R. 2008. Staphylococcus aureus antigens and challenges in vaccine development. Expert Rev. Vaccines 7(6):805-815.

Middleton, J. R., C. D. Luby, and D. S. Adams. 2009. Efficacy of vaccination against staphylococcal mastitis: a review and new data. Vet. Microbiol. 134(1-2):192-198.

Middleton, J. R., J. Ma, C. L. Rinehart, V. N. Taylor, C. D. Luby, and B. J. Steevens. 2006. Efficacy of different Lysigin formulations in the prevention of Staphylococcus aureus intramammary infection in dairy heifers. J. Dairy Res. 73(1):s10-19.

Misra, N., T. F. Wines, C. L. Knopp, R. Hermann, L. Bond, B. Mitchell, M. A. McGuire, and J. K. Tinker. 2018. Immunogenicity of a Staphylococcus aureus-cholera toxin A(2)/B vaccine for bovine mastitis. Vaccine 36(24):3513-3521.

Mistry, H., P. Sharma, S. Mahato, R. Saravanan, P. A. Kumar, and V. Bhandari. 2016. Prevalence and Characterization of Oxacillin Susceptible mecA-Positive Clinical Isolates of Staphylococcus aureus Causing Bovine Mastitis in India. PLoS ONE 11(9):e0162256.

Morris, D. D., J. S. Cullor, R. H. Whitlock, M. Wickstrom, and L. B. Corbeil. 1986. Endotoxemia in neonatal calves given antiserum to a mutant Escherichia coli (J-5). Am. J. Vet. Res. 47(12):2554-2565.

Mweu, M. M., S. S. Nielsen, T. Halasa, and N. Toft. 2012. Annual incidence, prevalence and transmission characteristics of Streptococcus agalactiae in Danish dairy herds. Prev. Vet. Med. 106(34):244-250.

NRC, C. s. o. t. r. c. o. t. n. m. council, R. J. Eberhart, R. P. Natzke, F. H. S. Newbould, B. Nonnecke, and P. Thompson. 1979. Coliform mastitis - A review. J. Dairy Sci. 62:1-22.

Oliveira, M., R. Bexiga, S. F. Nunes, C. Carneiro, L. M. Cavaco, F. Bernardo, and C. L. Vilela. 2006. Biofilm-forming ability profiling of Staphylococcus aureus and Staphylococcus epidermidis mastitis isolates. Vet. Microbiol. 118(1-2):133-140.

Omore, A. O., J. J. McDermott, S. M. Arimi, M. N. Kyule, and D. Ouma. 1996. A longitudinal study of milk somatic cell counts and bacterial culture from cows on smallholder dairy farms in Kiambu district, Kenya. Prev. Vet. Med. 29(1):77-89.

Paape, M., J. Mehrzad, X. Zhao, J. Detilleux, and C. Burvenich. 2002. Defense of the bovine mammary gland by polymorphonuclear neutrophil leukocytes. J Mammary Gland Biol. Neoplasia 7(2):109-121.

Pang, M. D., L. C. Sun, T. He, H. D. Bao, L. L. Zhang, Y. Zhou, H. Zhang, R. C. Wei, Y. J. Liu, and R. Wang. 2017. Molecular and virulence characterization of highly prevalent Streptococcus agalactiae circulated in bovine dairy herds. Vet. Res. 48.

Pankey, J. W., N. T. Boddie, J. L. Watts, and S. C. Nickerson. 1985. Evaluation of protein A and a commercial bacterin as vaccines against Staphylococcus aureus mastitis by experimental challenge. J. Dairy Sci. 68(3):726-731. 

J. M. Irache, T. Maira-Litran, J. Jimenez-Barbero, L. Costa, G. B. Pier, D. de Andres, and B. Amorena. 2009. Protection from Staphylococcus aureus mastitis associated with poly-N-acetyl beta-1,6 glucosamine specific antibody production using biofilm-embedded bacteria. Vaccine 27(17):23792386.

Petrovski, K. R., N. B. Williamson, N. Lopez-Villalobos, T. J. Parkinson, and I. G. Tucker. 2011. Culture results from milk samples submitted to veterinary diagnostic laboratories from August 2003 to December 2006 in New Zealand. New Zealand Vet. J. 59(6):317-322.

Petzer, I. M., J. Karzis, J. C. Watermeyer, T. J. van der Schans, and R. van Reenen. 2009. Trends in udder health and emerging mastitogenic pathogens in South African dairy herds. J. S. Afr. Vet. Assoc. 80(1):17-22.

Poutrel, B., S. Bareille, G. Lequeux, and F. Leboeuf. 2018. Prevalence of mastitis pathogens in France: antimicrobial susceptibility of Staphylococcus aureus, Streptococcus uberis and Escherichia coli. J Vet. Sci. Technol. 9:2.

P.outrel, B., P. Rainard, and P. Sarradin. 1997. Heterogeneity of cell-associated CP5 expression on Staphylococcus aureus strains demonstrated by flow cytometry. Clin. Diagn. Lab. Immunol. $4(3): 275-278$.

Poutrel, B. and L. Sutra. 1993. Type 5 and 8 capsular polysaccharides are expressed by Staphylococcus aureus isolates from rabbits, poultry, pigs, and horses. J.Clin.Microbiol. 31(2):467469. 2011. Vaccination of dairy cows with recombinant Streptococcus uberis adhesion molecule induces antibodies that reduce adherence to and internalization of S. uberis into bovine mammary epithelial cells. Vet. Immunol. Immunopathol. 141(3-4):201-208.

Prenafeta, A., R. March, A. Foix, I. Casals, and L. Costa. 2010. Study of the humoral immunological response after vaccination with a Staphylococcus aureus biofilm-embedded bacterin in dairy cows: Possible role of the exopolysaccharide specific antibody production in the protection from Staphylococcus aureus induced mastitis. Vet. Immunol. Immunopathol. 134(3-4):208-217. Herrera, O. Franquesa, L. Urtado, I. Calm, R. Collado, A. Prenafeta, R. March, and D. Sabaté. 2018. Efficacy under field conditions of the new vaccine UBAC ${ }^{\circledR}$ in the reduction of Streptococcus uberis clinical mastitis in dairy cows during a whole lactation period. in Proc. NMC 2018. NMC 2018. The 2018 international bovine mastitis conference, Milan.

Rainard, P. 1983. Experimental mastitis with Escherichia coli: sequential response of leukocytes and opsonic activity in milk of immunised and unimmunised cows. Ann. Rech. Vet. 14(3):281-286. 
Rainard, P. 1992. Isotype antibody response in cows to Streptococcus agalactiae group B polysaccharide-ovalbumin conjugate. J.Clin.Microbiol. 30(7):1856-1862.

Rainard, P., P. Cunha, R. P. Martins, F. B. Gilbert, P. Germon, and G. Foucras. 2020. Type 3 immunity: a perspective for the defense of the mammary gland against infections. Vet. Res. 51(1):129.

Rainard, P., G. Foucras, J. R. Fitzgerald, J. L. Watts, G. Koop, and J. R. Middleton. 2018. Knowledge gaps and research priorities in Staphylococcus aureus mastitis control. Transbound. Emerging Dis. 65(Suppl. 1):149-165.

Rainard, P., Y. Lautrou, P. Sarradin, A. Coulibaly, and B. Poutrel. 1991. The kinetics of inflammation and phagocytosis during bovine mastitis induced by Streptococcus agalactiae bearing the protein X. Vet. Res. Commun. 15(3):163-176.

Rainard, P., M. Reperant-Ferter, C. Gitton, and P. Germon. 2021. Shielding Effect of Escherichia coli O-Antigen Polysaccharide on J5-Induced Cross-Reactive Antibodies. mSphere 6(1):e01227-20.

Rainard, P. and C. Riollet. 2003. Mobilization of neutrophils and defense of the bovine mammary gland. Reprod. Nutr. Dev. 43(5):439-457.

Reiter, B. 1978. Review of the progress of dairy science: antimicrobial systems in milk. J.Dairy Res. 45(1):131-147.

Rosini, R., E. Campisi, M. De Chiara, H. Tettelin, D. Rinaudo, C. Toniolo, M. Metruccio, S. Guidotti, U. B. Sorensen, M. Kilian, M. Ramirez, R. Janulczyk, C. Donati, G. Grandi, and I. Margarit. 2015. Genomic analysis reveals the molecular basis for capsule loss in the group B streptococcus population. PLoS ONE 10(5):e0125985.

Ruegg, P. L. 2017. A 100-Year Review: Mastitis detection, management, and prevention. J. Dairy Sci. 100(12):10381-10397.

Sakulramrung, R. and G. J. Domingue. 1985. Cross-Reactive Immunoprotective Antibodies to Escherichia-coli 0111 Rough Mutant J5. J. Infect. Dis. 151(6):995-1004.

Sampimon, O., H. W. Barkema, I. Berends, J. Sol, and T. Lam. 2009. Prevalence of intramammary infection in Dutch dairy herds. J. Dairy Res. 76(2):129-136.

Sanchez-Carlo, V., R. A. Wilson, J. S. McDonald, and R. A. Packer. 1984. Biochemical and serologic properties of Escherichia coli isolated from cows with acute mastitis. Am. J. Vet. Res. 45(9):1771-1774.

Scali, F., C. Camussone, L. F. Calvinho, M. Cipolla, and A. Zecconi. 2015. Which are important targets in development of $S$. aureus mastitis vaccine? Res. Vet. Sci. 100:88-99.

Schukken, Y. H., V. Bronzo, C. Locatelli, C. Pollera, N. Rota, A. Casula, F. Testa, L. Scaccabarozzi, R. March, D. Zalduendo, R. Guix, and P. Moroni. 2014. Efficacy of vaccination on Staphylococcus 
aureus and coagulase-negative staphylococci intramammary infection dynamics in 2 dairy herds. J. Dairy Sci. 97(8):5250-5264.

Shafer-Weaver, K. A., C. M. Corl, and L. M. Sordillo. 1999. Shifts in bovine CD4+ subpopulations increase T-helper-2 compared with T-helper-1 effector cells during the postpartum period. J. Dairy Sci. 82(8):1696-1706.

Shkreta, L., B. G. Talbot, M. S. Diarra, and P. Lacasse. 2004. Immune responses to a DNA/protein vaccination strategy against Staphylococcus aureus induced mastitis in dairy cows. Vaccine 23(1):114-126.

Siebert, L., S. Headrick, M. Lewis, B. Gillespie, C. Young, L. Wojakiewicz, O. Kerro-Dego, M. E. Prado, R. Almeida, S. P. Oliver, and G. M. Pighetti. 2017. Genetic variation in CXCR1 haplotypes linked to severity of Streptococcus uberis infection in an experimental challenge model. Vet. Immunol. Immunopathol. 190:45-52.

Skaar, E. P. and O. Schneewind. 2004. Iron-regulated surface determinants (Isd) of Staphylococcus aureus: stealing iron from heme. Microbes Infect. 6(4):390-397.

Slanetz, L. W., C. H. Bartley, and F. E. Allen. 1965. Evaluation of Cell-Toxoid Vaccines for the Vaccination of Dairy Cattle against Staphylococcic Mastitis. Am. J. Vet. Res. 26:688-695.

Smith, J. L., J. S. Hogan, and K. L. Smith. 1999. Efficacy of intramammary immunization with an Escherichia coli J5 bacterin. J. Dairy Sci. 82(12):2582-2588.

Song, B. F., X. J. Yang, H. N. Sun, L. Q. Yu, J. Z. Ma, Z. J. Wu, and Y. D. Cui. 2017. Immunogenicity of amino acids 1-150 of Streptococcus GapC displayed on the surface of Escherichia coli. Microb. Pathog. 105:288-297.

Song, J. Y., J. H. Lim, S. Lim, Z. Yong, and H. S. Seo. 2018. Progress toward a group B streptococcal vaccine. Hum. Vacc. Immunother. 14(11):2669-2681.

Stark, D. M. and N. L. Norcross. 1970. Response of bovine to immunization against Streptococcus dysgalactiae. Cornell Vet. 60(4):604-612.

Steele, N. M., T. H. Swartz, K. M. Enger, H. Schramm, R. R. Cockrum, S. J. Lacy-Hulbert, R. R. White, J. Hogan, and C. S. Petersson-Wolfe. 2019. The effect of J5 bacterins on clinical, behavioral, and antibody response following an Escherichia coli intramammary challenge in dairy cows at peak lactation. J. Dairy Sci. 112(12):11233-11249.

Stenutz, R., A. Weintraub, and G. Widmalm. 2006. The structures of Escherichia coli Opolysaccharide antigens. FEMS Microbiol. Rev. 30(3):382-403.

Ster, C., F. Beaudoin, M. S. Diarra, M. Jacques, F. Malouin, and P. Lacasse. 2010. Evaluation of some Staphylococcus aureus iron-regulated proteins as vaccine targets. Vet. Immunol. Immunopathol. 136(3-4):311-318. 
Sutra, L., C. Mendolia, P. Rainard, and B. Poutrel. 1990a. Encapsulation of Staphylococcus aureus isolates from mastitic milk: relationship between capsular polysaccharide types 5 and 8 and colony morphology in serum-soft agar, clumping factor, teichoic acid, and protein A. J.Clin.Microbiol. 28(3):447-451.

Sutra, L., P. Rainard, and B. Poutrel. 1990b. Phagocytosis of mastitis isolates of Staphylococcus aureus and expression of type 5 capsular polysaccharide are influenced by growth in the presence of milk. J.Clin.Microbiol. 28(10):2253-2258.

Takemura, K., J. S. Hogan, J. Lin, and K. L. Smith. 2002. Efficacy of immunization with ferric citrate receptor FecA from Escherichia coli on induced coliform mastitis. J. Dairy Sci. 85(4):774-781.

Takemura, K., J. S. Hogan, and K. L. Smith. 2004. Growth responses of Escherichia coli to immunoglobulin G from cows immunized with ferric citrate receptor, FecA. J. Dairy Sci. 87(2):316320.

Tamilselvam, B., R. A. Almeida, J. R. Dunlap, and S. P. Oliver. 2006. Streptococcus uberis internalizes and persists in bovine mammary epithelial cells. Microb. Pathog. 40(6):279-285.

Tashakkori, N., B. Khoramian, M. Farhoodi Moghadam, M. Heidarpour, K. Mashayekhi, and N. Farzaneh. 2020. Evaluating the effectiveness of two bovine mastitis vaccines and their influences on oxidant and antioxidant capacities of milk. Trop. Anim. Health Prod. 52(3):1493-1501.

Tassi, R., T. N. McNeilly, J. L. Fitzpatrick, M. C. Fontaine, D. Reddick, C. Ramage, M. Lutton, Y. H. Schukken, and R. N. Zadoks. 2013. Strain-specific pathogenicity of putative host-adapted and nonadapted strains of Streptococcus uberis in dairy cattle. J. Dairy Sci. 96(8):5129-5145.

Taylor, B. C., J. D. Dellinger, J. S. Cullor, and J. L. Stott. 1994. Bovine milk lymphocytes display the phenotype of memory T cells and are predominantly CD8+. Cell. Immunol. 156(1):245-253.

Thomas, L. H., W. Haider, A. W. Hill, and R. S. Cook. 1994. Pathologic findings of experimentally induced Streptococcus uberis infection in the mammary gland of cows. Am. J. Vet. Res. 55(12):17231728.

Thomas, L. H., J. A. Leigh, A. P. Bland, and R. S. Cook. 1992. Adherence and colonization by bacterial pathogens in explant cultures of bovine mammary tissue. Vet. Res. Commun. 16(2):87-96.

Tomazi, T., A. C. C. H. Tomazi, J. C. C. Silva, L. Bringhenti, M. L. M. C. Bravo, M. X. Rodrigues, and R. C. Bicalho. 2021. Immunization with a novel recombinant protein (YidR) reduced the risk of clinical mastitis caused by Klebsiella spp. and decreased milk losses and culling risk after Escherichia coli infections. Journal of Dairy Science 104(4):4787-4802.

Tomita, G. M., S. C. Nickerson, W. E. Owens, and B. Wren. 1998. Influence of route of vaccine administration against experimental intramammary infection caused by Escherichia coli. J. Dairy Sci. $81(8): 2159-2164$. 

two commercially available Escherichia coli 55 vaccines against E. coli intramammary challenge. J. Dairy Sci. 83(10):2276-2281.

Tuchscherr, L., B. Loffler, F. R. Buzzola, and D. O. Sordelli. 2010. Staphylococcus aureus adaptation to the host and persistence: role of loss of capsular polysaccharide expression. Future Microbiol. 5(12):1823-1832.

Tuchscherr, L. P., F. R. Buzzola, L. P. Alvarez, R. L. Caccuri, J. C. Lee, and D. O. Sordelli. 2005. Capsule-negative Staphylococcus aureus induces chronic experimental mastitis in mice. Infect. Immun. 73(12):7932-7937.

Tyler, J. W., J. S. Cullor, B. I. Osburn, R. B. Bushnell, and B. W. Fenwick. 1988. Relationship between serologic recognition of Escherichia coli 0111:B4 (J5) and clinical coliform mastitis in cattle. Am. J. Vet. Res. 49(11):1950-1954.

van Dijk, W. C., H. A. Verbrugh, M. E. van Erne-van der Tol, R. Peters, and J. Verhoef. 1981. Escherichia coli antibodies in opsonisation and protection against infection. J. Med. Microbiol. 14(4):381-389.

Vangroenweghe, F., L. Duchateau, and C. Burvenich. 2020. Short communication: J-5 Escherichia coli vaccination does not influence severity of an Escherichia coli intramammary challenge in primiparous cows. J. Dairy Sci. 103(7):6692-6697.

Varhimo, E., P. Varmanen, A. Fallarero, M. Skogman, S. Pyorala, A. Livanainen, A. Sukura, P. Vuorela, and K. Savijoki. 2011. Alpha- and beta-casein components of host milk induce biofilm formation in the mastitis bacterium Streptococcus uberis. Vet. Microbiol. 149(3-4):381-389. in Staphylococcus aureus isolates recovered from human and animals species. Vet. Microbiol. 127(34):407-411.

Verdier, I., G. Durand, M. Bes, K. L. Taylor, G. Lina, F. Vandenesch, A. I. Fattom, and J. Etienne. 2007. Identification of the capsular polysaccharides in Staphylococcus aureus clinical isolates by PCR and agglutination tests. J. Clin. Microbiol. 45(3):725-729.

Vreede, R. W., J. H. Marcelis, and J. Verhoef. 1986. Antibodies raised against rough mutants of Escherichia coli and Salmonella strains are opsonic only in the presence of complement. Infect. Immun. 52(3):892-896.

Ward, P. N., T. R. Field, W. G. Ditcham, E. Maguin, and J. A. Leigh. 2001. Identification and disruption of two discrete loci encoding hyaluronic acid capsule biosynthesis genes has A, hasB, and hasC in Streptococcus uberis. Infect. Immun. 69(1):392-399.

Ward, P. N., T. R. Field, C. D. Rapier, and J. A. Leigh. 2003. The activation of bovine plasminogen by PauA is not required for virulence of Streptococcus uberis. Infect. Immun. 71(12):7193-7196. 
Warren, H. S., S. F. Amato, C. Fitting, K. M. Black, P. M. Loiselle, M. S. Pasternack, and J. M. Cavaillon. 1993. Assessment of Ability of Murine and Human Antilipid-a Monoclonal-Antibodies to Bind and Neutralize Lipopolysaccharide. J. Exp. Med. 177(1):89-97.

Watson, D. L. 1981. Immunologically-specific resistance to infection with particular reference to staphylococcal mastitis. Adv. Exp. Med. Biol. 137:579-590.

Watson, D. L. 1992a. Staphylococcal mastitis vaccine. Vaccine 10(5):359.

Watson, D. L. 1992b. Vaccination against experimental staphylococcal mastitis in dairy heifers. Res. Vet. Sci. 53(3):346-353.

Watson, D. L. and J. W. Kennedy. 1981. Immunisation against experimental staphylococcal mastitis in sheep - effect of challenge with a heterologous strain of Staphylococcus aureus. Aust. Vet. J. 57(7):309-313.

Wedlock, D. N., B. M. Buddle, J. Williamson, S. J. Lacy-Hulbert, S. A. Turner, S. Subharat, and A. Heiser. 2014. Dairy cows produce cytokine and cytotoxic T cell responses following vaccination with an antigenic fraction from Streptococcus uberis. Vet. Immunol. Immunopathol. 160(1-2):51-60.

Whitnack, E., A. L. Bisno, and E. H. Beachey. 1981. Hyaluronate capsule prevents attachment of group A streptococci to mouse peritoneal macrophages. Infect. Immun. 31(3):985-991.

Williams, M. R. and A. W. Hill. 1982. A role for IgM in the in vitro opsonisation of Staphylococcus aureus and Escherichia coli by bovine polymorphonuclear leucocytes. Res. Vet. Sci. 33(1):47-53.

Wilson, D. J. and R. N. Gonzalez. 2003. Vaccination strategies for reducing clinical severity of coliform mastitis. Vet. Clin. North Am. Food Anim. Pract. 19(1):187-197, vii-viii.

Wilson, D. J., Y. T. Grohn, G. J. Bennett, R. N. Gonzalez, Y. H. Schukken, and J. Spatz. 2007. Comparison of $\mathrm{J} 5$ vaccinates and controls for incidence, etiologic agent, clinical severity, and survival in the herd following naturally occurring cases of clinical mastitis. J. Dairy Sci. 90(9):4282-4288.

Wolf, S. L., J. S. Hogan, and K. L. Smith. 2004. Iron uptake by Escherichia coli cultured with antibodies from cows immunized with high-affinity ferric receptors. J. Dairy Sci. 87(7):2103-2107. Yancey, R. J., Jr. 1993. Recent advances in bovine vaccine technology. J.Dairy Sci. 76(8):24182436.

Yao, D., H. Zhang, X. Wang, S. Yu, Y. Wei, W. Liu, J. Wang, X. Chen, Z. Zhang, H. Sun, L. Yu, J. Ma, C. Tong, B. Song, and Y. Cui. 2016. Identification and characterization of CD4(+) T-cell epitopes on GapC protein of Streptococcus dysgalactiae. Microb. Pathog. 91:46-53.

Yu, L., Z. Fan, J. Ma, C. Tong, B. Song, Z. Zhu, and Y. Cui. 2014. Cross-protective effect of a novel multi-antigen-chimeric vaccine against Streptococcus and Staphylococcus aureus infection in mice. J. Med. Microbiol. 63(Pt 12):1732-1740. 
1382 Han. 2018. Phenotypic and genotypic characterization of antimicrobial resistance profiles in

1383 Streptococcus dysgalactiae isolated from bovine clinical mastitis in 5 provinces of China. J. Dairy Sci.

1384 101(4):3344-3355.

1385

Ziegler, E. J., H. Douglas, J. E. Sherman, C. E. Davis, and A. I. Braude. 1973. Treatment of E. coli and klebsiella bacteremia in agranulocytic animals with antiserum to a UDP-gal epimerase-deficient mutant. J. Immunol. 111(2):433-438.

Ziegler, E. J., J. A. McCutchan, J. Fierer, M. P. Glauser, J. C. Sadoff, H. Douglas, and A. I. Braude.

1389 1982. Treatment of Gram-negative bacteremia and shock with human antiserum to a mutant

1390 Escherichia coli. N. Engl. J. Med. 307(20):1225-1230. 


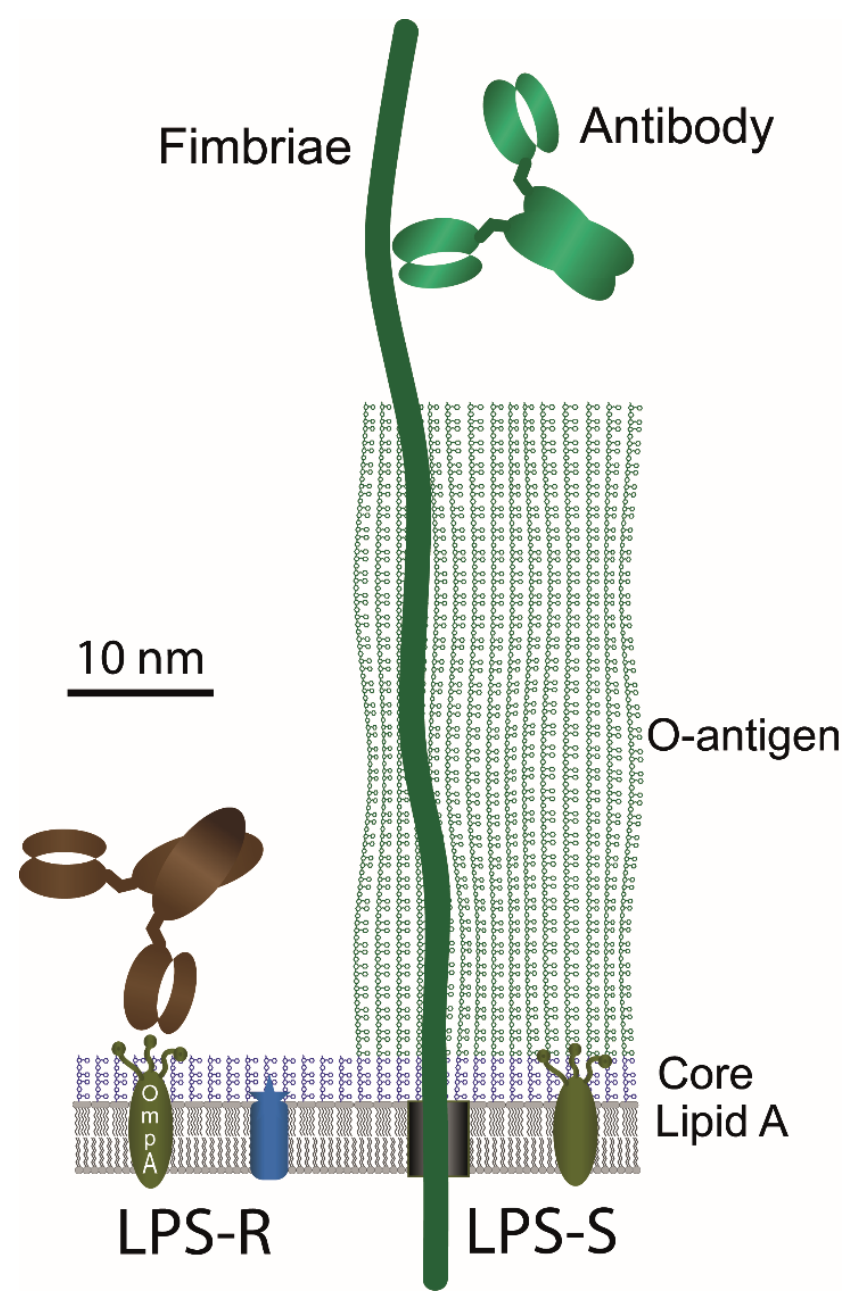

Figure 1. Steric hindrance for antibody accessibility to E. coli outer membrane of rough (LPS-R) or smooth (LPS-S) strains. Antibodies can access outer membrane proteins such as OmpA on rough strains, but are prevented from reacting with these proteins by the shielding 1397 effect of the 0 -antigen of smooth strains. However, bacterial structures protruding from the smooth LPS, such as fimbriae, are accessible to antibodies. The IgG molecule of antibody is shown to scale for comparison with the bacterial components. The LPS-S of E. coli O32 with 15 repeats of the O-antigen unit is shown. 
1406

1407

\section{Lumen}

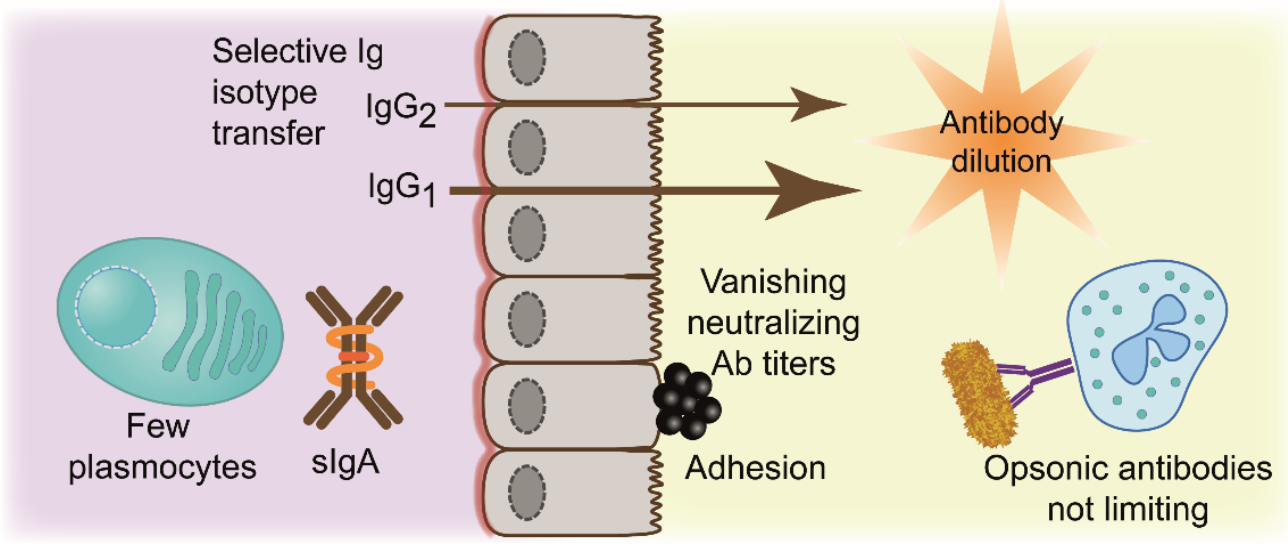

Figure 2. Vaccine-induced antibodies and antibody-dependent MG defenses face several challenges. In healthy glands, passive transudation of antibodies from blood to milk is low. Active transepithelial transfer favors the $\mathrm{IgG}_{1}$ isotype, which is not opsonic for neutrophils. Local production of antibodies, such as secretory $\operatorname{IgA}(\operatorname{sgA})$ is limited, as resident plasmocytes are few in the mammary parenchyma. In addition, antibodies that pass the epithelial barrier are diluted in high volumes of milk. In the absence of apical mucus capable of retaining antibodies on the luminal surface of the epithelium, antibody concentrations is locally not sufficient to prevent adhesion of bacteria or interfering with nutrient acquisition. Furthermore, elevated antibody concentrations to common mastitis-causing bacteria in blood and milk are transient after vaccination. Finally, there are few examples of increased opsonic activity towards mastitis bacteria following vaccination. This latter failure is largely because natural antibodies in milk and blood already have fairly good opsonic activity, so opsonic antibodies are usually not the limiting factor for protection. 


\begin{tabular}{|c|c|c|c|c|}
\hline Vaccine antigens & Targeted or putative effect & Efficacy & Pitfalls or knowledge gaps & Salient references \\
\hline E. coli J5 bacterins & $\begin{array}{l}\text { Antibodies to LPS core } \\
\text { antigen }\end{array}$ & $\begin{array}{l}\text { Decreased coliform mastitis } \\
\text { severity in field experiments }\end{array}$ & $\begin{array}{l}\text { Variable effect on incidence } \\
\text { of cases } \\
\text { Unknown mechanism }\end{array}$ & $\begin{array}{l}\text { (Gonzalez et al., 1989) } \\
\text { (Cullor, 1991) } \\
\text { (Hogan et al., 1992a) }\end{array}$ \\
\hline $\begin{array}{l}\text { Salmonella Re-17 bacterin } \\
\text { toxoid }\end{array}$ & $\begin{array}{l}\text { Antibodies to LPS core } \\
\text { antigen }\end{array}$ & $\begin{array}{l}\text { Decreased coliform mastitis } \\
\text { severity in field experiment }\end{array}$ & Unknown mechanism & (McClure et al., 1994) \\
\hline E. coli J5 bacterin & $\begin{array}{l}\text { Antibodies to LPS core } \\
\text { antigens }\end{array}$ & $\begin{array}{l}\text { Discrepant results: } \\
\text { reduction or not of severity } \\
\text { in experimental infection }\end{array}$ & Unknown mechanism & $\begin{array}{l}\text { (Hogan et al., 1992c) } \\
\text { (Hill, 1991) }\end{array}$ \\
\hline $\begin{array}{l}\text { E. coli J5 bacterin, } \\
\text { hyperimmunization }\end{array}$ & $\begin{array}{l}\text { Antibodies to coliform outer } \\
\text { membrane antigens in the } \\
\operatorname{lgG}_{2} \text { isotype }\end{array}$ & $\begin{array}{l}\text { Decreased occurrence of } \\
\text { severe mastitis compared to } \\
\text { usual schedule }\end{array}$ & $\begin{array}{l}\text { Variable among herds } \\
\text { Unknown mechanism }\end{array}$ & (Erskine et al., 2007) \\
\hline $\begin{array}{l}\text { E. coli J5 bacterin with killed } \\
\text { S. aureus (StartVac) }\end{array}$ & $\begin{array}{l}\text { Antibodies to coliform outer } \\
\text { membrane antigens }\end{array}$ & $\begin{array}{l}\text { Decreased mastitis severity } \\
\text { in a field study }\end{array}$ & $\begin{array}{l}\text { No reduction in incidence of } \\
\text { case. Unknown mechanism }\end{array}$ & (Bradley et al., 2015) \\
\hline Enterobactin FepA & Iron acquisition & $\begin{array}{l}\text { Growth reduction in dry } \\
\text { mammary secretion }\end{array}$ & $\begin{array}{l}\text { Likely not active in lactation, } \\
\text { not tested in vivo }\end{array}$ & (Lin et al., 1999) \\
\hline Siderophore receptor FecA & Iron acquisition & $\begin{array}{l}\text { None in experimental } \\
\text { infection }\end{array}$ & $\begin{array}{l}\text { Antibody titer insufficient in } \\
\text { milk }\end{array}$ & $\begin{array}{l}\text { (Takemura et al., 2002) } \\
\text { (Wolf et al., 2004) }\end{array}$ \\
\hline $\begin{array}{l}\text { Whole E. coli (P4), } \\
\text { intramammary booster with } \\
\text { bacterial extract }\end{array}$ & $\begin{array}{l}\text { Antibody and cell-mediated } \\
\text { responses }\end{array}$ & $\begin{array}{l}\text { Reduction in severity, likely } \\
\text { independent of antibodies, } \\
\text { related to Th17 response }\end{array}$ & $\begin{array}{l}\text { Heterologous protection not } \\
\text { tested }\end{array}$ & (Herry et al., 2017) \\
\hline $\begin{array}{l}\text { Klebsiella Siderophore } \\
\text { receptors and porin proteins } \\
\left.\text { (KlebVax }{ }^{\mathrm{TM}}\right)\end{array}$ & $\begin{array}{l}\text { Iron acquisition and multiple } \\
\text { bacterial functions } \\
\text { With antibodies }\end{array}$ & $\begin{array}{l}\text { Effective in one small scale } \\
\text { study, ineffective in a large } \\
\text { scale study }\end{array}$ & & $\begin{array}{l}\text { (Gorden et al., 2018, Tomazi } \\
\text { et al., 2021) }\end{array}$ \\
\hline Klebsiella recombinant YidR & $\begin{array}{l}\text { Unknown bacterial functions } \\
\text { With antibodies }\end{array}$ & $\begin{array}{l}\text { Reduced incidence of } \\
\text { Klebsiella clinical mastitis }\end{array}$ & $\begin{array}{l}\text { No effect on risk of death if } \\
\text { clinical } \\
\text { Little antibody response to } \\
\text { whole bacteria and activity } \\
\text { unknown }\end{array}$ & (Tomazi et al., 2021) \\
\hline
\end{tabular}




\begin{tabular}{|c|c|c|c|c|}
\hline Vaccine antigens & Targeted or putative effect & Efficacy & Pitfalls or knowledge gaps & Salient references \\
\hline $\begin{array}{l}\text { Whole killed bacteria and } \\
\text { toxoid }\end{array}$ & $\begin{array}{l}\text { Opsonization and } \\
\text { neutralizing antibodies }\end{array}$ & $\begin{array}{l}\text { Reduction in severity, } \\
\text { intramammary challenge }\end{array}$ & $\begin{array}{l}\text { No self-cure, homologous } \\
\text { challenge }\end{array}$ & (Derbyshire, 1960) \\
\hline $\begin{array}{l}\text { Bacterial lysate (5 strains) } \\
\text { Lysigin }{ }^{\circledast} \text { (Boehringer } \\
\text { Ingelheim Vetmedica) }\end{array}$ & Antibodies & $\begin{array}{l}\text { Some reduction in severity } \\
\text { and incidence of IMI }\end{array}$ & Variable results & $\begin{array}{l}\text { (Middleton et al., 2006) } \\
\text { (Middleton et al., 2009) }\end{array}$ \\
\hline Live vaccine, subcutaneous & $\begin{array}{l}\text { Opsonization by } \lg G_{2} \\
\text { antibodies }\end{array}$ & $\begin{array}{l}\text { Better reduction in severity } \\
\text { than killed vaccine, boosted } \\
\text { recruitment of neutrophils }\end{array}$ & $\begin{array}{l}\text { Challenge of ewes } \\
\text { Mechanism not identified }\end{array}$ & $\begin{array}{l}\text { (Watson and Kennedy, } \\
\text { 1981) } \\
\text { (Colditz and Watson, 1982) }\end{array}$ \\
\hline $\begin{array}{l}\text { Killed vaccine, "in vivo" } \\
\text { antigen and dextran sulfate }\end{array}$ & $\begin{array}{l}\text { Opsonization by } \lg G_{2} \\
\text { antibodies }\end{array}$ & Reduced severity & & (Watson, 1992b) \\
\hline $\begin{array}{l}\text { Capsular polysaccharides } \\
\text { (CP5, CP8, teichoic acid) }\end{array}$ & $\begin{array}{l}\text { Opsonization by antibodies, } \\
\text { cell-mediated immunity }\end{array}$ & $\begin{array}{l}\text { Slight increase in } \\
\text { opsonization, }\end{array}$ & No protection study & (Lee et al., 2005) \\
\hline $\begin{array}{l}\text { Slime on killed bacteria, } \\
\text { StartVac }{ }^{\circledast} \text { (Hipra) }\end{array}$ & Opsonization, adhesion & $\begin{array}{l}\text { Reduction in bacterial } \\
\text { shedding in milk }\end{array}$ & $\begin{array}{l}\text { Mechanism not identified } \\
\text { Little effect on severity and } \\
\text { incidence of new IMI }\end{array}$ & $\begin{array}{l}\text { (Prenafeta et al., 2010) } \\
\text { (Schukken et al., 2014) }\end{array}$ \\
\hline Live VraG mutant SCV & $\begin{array}{l}\text { Antibodies \& cell-mediated } \\
\text { immunity }\end{array}$ & $\begin{array}{l}\text { Humoral and cell-mediated } \\
\text { response of Th1/Th17 type }\end{array}$ & Mouse model, no challenge & (Côté-Gravel et al., 2016) \\
\hline Protein A (SpA) & antibodies & $\begin{array}{l}\text { Increased spontaneous cure } \\
\text { of } S \text {. aureus IMI after } \\
\text { experimental challenge }\end{array}$ & $\begin{array}{l}\text { No field trial } \\
\text { Mechanism not identified }\end{array}$ & (Pankey et al., 1985) \\
\hline FnBP and ClfA & $\begin{array}{l}\text { Antibodies and cell- } \\
\text { mediated immunity }\end{array}$ & $\begin{array}{l}\text { Increased spontaneous cure } \\
\text { of } S \text {. aureus IMI after } \\
\text { experimental challenge }\end{array}$ & $\begin{array}{l}\text { No field trial } \\
\text { Mechanism not identified }\end{array}$ & (Shkreta et al., 2004) \\
\hline Recombinant IsdB and IsdH & $\begin{array}{l}\text { Antibodies interfering with } \\
\text { iron acquisition, } \\
\text { opsonization }\end{array}$ & $\begin{array}{l}\text { IgG2 antibodies and antigen- } \\
\text { specific lymphoproliferation }\end{array}$ & No protection study in cows & (Ster et al., 2010) \\
\hline GapB and GapC & Antibodies & Immunogenic in mice & No protection study in cows & (Kerro-Dego et al., 2006) \\
\hline
\end{tabular}


